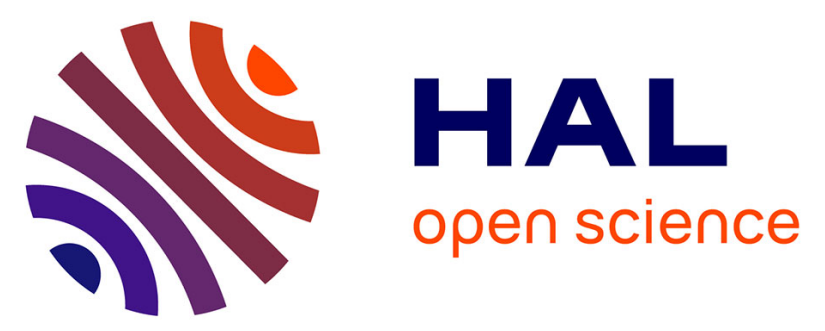

\title{
Compatibility between Activity and Selectivity in Catalytic Oxidation of Benzyl Alcohol with Au-Pd Nanoparticle through Redox Switching of $\mathrm{SnO} \times$
} Pingping Wu, Zhengke He, Yonghui Liu, Lei Song, Chunzheng Wang, Edgar Muhumuza, Peng Bai, Lianming Zhao, Svetlana Mintova, Zifeng Yan

\section{To cite this version:}

Pingping Wu, Zhengke He, Yonghui Liu, Lei Song, Chunzheng Wang, et al.. Compatibility between Activity and Selectivity in Catalytic Oxidation of Benzyl Alcohol with Au-Pd Nanoparticle through Redox Switching of SnO x. ACS Applied Materials \& Interfaces, 2021, 13 (42), pp.49780-49792. 10.1021/acsami.1c10207 . hal-03416067

\section{HAL Id: hal-03416067 https://hal.science/hal-03416067}

Submitted on 5 Nov 2021

HAL is a multi-disciplinary open access archive for the deposit and dissemination of scientific research documents, whether they are published or not. The documents may come from teaching and research institutions in France or abroad, or from public or private research centers.
L'archive ouverte pluridisciplinaire HAL, est destinée au dépôt et à la diffusion de documents scientifiques de niveau recherche, publiés ou non, émanant des établissements d'enseignement et de recherche français ou étrangers, des laboratoires publics ou privés. 


\section{Compatibility between Activity and Selectivity in Catalytic Oxidation of Benzyl Alcohol with $\mathrm{Au}-\mathrm{Pd}$ Nanoparticle through Redox Switching of $\mathrm{SnO}_{x}$}

Pingping Wu, ${ }^{\ddagger}$ Zhengke He, ${ }^{\ddagger}$ Yonghui Liu, ${ }^{\#}$ Lei Song, ${ }^{\ddagger}$ Chunzheng Wang, ${ }^{\ddagger}$ Edgar

Muhumuza, ${ }^{\ddagger}$ Peng Bai, ${ }^{\ddagger} *$ Lianming Zhao, ${ }^{\#, *}$ Svetlana Mintova, ${ }^{\prime \prime}$ Zifeng Yan ${ }^{\ddagger}$

${ }^{\ddagger}$ State Key Laboratory of Heavy Oil Processing, CNPC Key Laboratory of Catalysis, College of Chemical Engineering, China University of Petroleum (East China), Qingdao 266580, China

${ }^{\#}$ School of Materials Science and Engineering, Institute of Advanced Materials, China University of Petroleum (East China), Qingdao, 266580, China

"Normandie University, ENSICAEN, UNICAEN, CNRS, Laboratoire Catalyse et Spectrochimie, 14000 Caen, France 
ABSTRACT: A balance between the catalytic activity and product selectivity remains a dilemma for the partial oxidation processes because the products are prone to be over-oxidized. In this work we report on the partial oxidation of benzyl alcohol using a modified catalyst consisting of nanosized Au-Pd particles (NP) with tin oxide $\left(\mathrm{SnO}_{\mathrm{x}}\right)$ deposited on mesoporous silica support. We found that the $\mathrm{SnO}_{\mathrm{x}}$ promotes the autogenous reduction of $\mathrm{PdO}$ to active $\mathrm{Pd}^{0}$ species on the Au-Pd NP catalyst ( $\mathrm{SnO}_{\mathrm{x}} @ \mathrm{AP}$-ox) before $\mathrm{H}_{2}$ reduction, which is due to the high oxophilicity of $\mathrm{Sn}$. The presence of active $\mathrm{Pd}^{0}$ species and the enhancement of oxygen transfer by $\mathrm{SnO}_{\mathrm{x}}$ led to a high catalytic activity. The benzaldehyde selectivity was enhanced with the increase of $\mathrm{SnO}_{\mathrm{x}}$ content on catalyst $\mathrm{SnO}_{\mathrm{x}} @ \mathrm{AP}-\mathrm{ox}$, which is ascribed to the modulated affinity of reactants and products on the catalyst surface through the redox switching of $\mathrm{Sn}$ species. After $\mathrm{H}_{2}$ reduction, the $\mathrm{SnO}_{\mathrm{x}}$ was partially reduced and $\mathrm{Au}-\mathrm{Pd}-\mathrm{Sn}$ alloy was formed. The formation of Au-Pd-Sn alloy weakened both the catalytic synergy of Au-Pd alloy NPs and the adsorption of benzyl alcohol on the reduced catalyst, thus leading to a low catalytic activity.

KEYWORDS: $\mathrm{SnO}_{\mathrm{x}}, \mathrm{Au}-\mathrm{Pd}$, oxygen transfer, alloying, benzyl alcohol oxidation

\section{INTRODUCTION}

The catalytic partial oxidation to produce various fine chemicals is a vital research area for the pharmaceutical, food, and cosmetic industries. ${ }^{1}$ One of such processes in the modern synthetic chemical industry is the catalytic partial oxidation of primary alcohols to their corresponding intermediates, ${ }^{2}$ such as benzyl alcohol oxidation to 
benzaldehyde, benzyl benzoate, benzoic acid and/or benzyl ether depending on the catalytic system and reaction conditions used. ${ }^{3-4}$ Among which benzaldehyde is considered as the most valuable product and widely used in the manufacture of flavors, pharmaceuticals, dyes, spices, etc..$^{5}$ Oxidizing a primary alcohol to an aldehyde using molecular oxygen/air as an oxidant conforms with the principles of green and sustainable chemical processes since water is the only by-product. ${ }^{1}$ However, the desired products are highly reactive and susceptible to over oxidization generating low-value by-products, which results in low product selectivity during selective oxidation with oxygen/air as oxidant. In the industrial process, high product selectivity is generally achieved through the control of conversion, which results in low single-pass conversion, excessive recovery of unreacted reactant and high energy consumption. Therefore, it has been a long-standing dilemma between the high activity and high selectivity for the partial oxidation catalysts.

Au-Pd bimetallic catalysts are the most frequently reported for benzyl alcohol partial oxidation; ${ }^{6-8}$ and a catalytic synergy between these two metals has been observed. This catalytic synergy was attributed to the formation of $\mathrm{Au}-\mathrm{Pd}$ alloy NPs and electrons transfer between surface $\mathrm{Au}$ and $\mathrm{Pd}$ atoms, preventing the formation of inert surface PdO species. ${ }^{8-10}$ Metallic $\mathrm{Pd}^{0}$-enriched clusters/surface has been reported as active sites for $\mathrm{O}_{2}$ activation, ${ }^{8-14}$ however, $\mathrm{Pd}$-enriched surfaces are usually coated with a layer of inert PdO. ${ }^{15-16}$ This contradictive condition has been improved to a certain extent by introducing $\mathrm{Au}$ to $\mathrm{Pd}$ with $\mathrm{H}_{2}$ reduction process. Electrons rearrangement between $\mathrm{Au}$ and $\mathrm{Pd}$ atoms facilitates the formation of metallic 
$\mathrm{Pd}^{0}$-enriched clusters/surface on $\mathrm{H}_{2}$ reduced Au-Pd bimetallic NP catalyst. ${ }^{16-17}$ However, Wiley and co-workers observed a surface enrichment of Au on Au-Pd alloy NPs after $\mathrm{H}_{2}$ reduction, resulting in a decrease of $\mathrm{Pd}^{0}$-enriched surface-active sites. ${ }^{16}$ These results pointed out to the need to find another route to reduce the surface inert PdO layers on Au-Pd NP catalyst. Pd has a relative high electron negativity and a low oxygen affinity, ${ }^{17-18}$ while $\mathrm{Sn}$ is considered as an oxophilic metal. ${ }^{17,}{ }^{19-20}$ Thus, this reminds us to consider the possibility of applying tin as a potential promoter for in-situ autogenous reduction of surface $\mathrm{PdO}$ layer instead of high temperature $\mathrm{H}_{2}$ reduction.

Meanwhile as we mentioned above, the dilemma between the high activity and high selectivity for benzyl alcohol partial oxidation also persists on Au-Pd bimetallic NP catalyst. A high benzyl alcohol conversion (> 90\%) was obtained on Au-Pd bimetallic catalysts but with a relative low benzaldehyde selectivity of $50 \% \sim 60 \%$. $^{8}$ Studies have shown that the introduction of auxiliaries can regulate the surface affinity to reactants, products or intermediates to reduce side reactions and improve product selectivity. ${ }^{13,21-22} \mathrm{He}$ et al. demonstrated that when a small amount of $\mathrm{Pt}$ metal was alloyed with Au-Pd sol, a high selectivity to benzaldehyde was achieved on the solvent-free oxidation of benzyl alcohol. ${ }^{1}$ Hutchings et al. applied $\mathrm{SnO}_{\mathrm{x}}$ promoted $\mathrm{Pd} / \mathrm{TiO}_{2}$ catalyst for hydrogen peroxide synthesis. ${ }^{13}$ The promoted catalyst exhibited high $\mathrm{H}_{2} \mathrm{O}_{2}$ selectivity attributable to the presence of the $\mathrm{SnO}_{\mathrm{x}}$ surface layer which prevented further hydrogenation and decomposition of $\mathrm{H}_{2} \mathrm{O}_{2}$. In our previous work, ${ }^{23}$ we found that applying $\mathrm{SnO}_{\mathrm{x}}$ promoted $\mathrm{Au}$ nanoparticle (NP) catalyst for benzyl 
alcohol oxidation can effectively reduce the disproportionation reaction, achieving a high benzaldehyde selectivity. In summary, tin is a potential promoter for in-situ reduction of surface $\mathrm{PdO}$ species because it is more oxophilic and it can also effectively enhance the benzaldehyde selectivity on Au NP catalyst by regulating the surface affinity. ${ }^{23}$

In this paper we report the preparation of Au-Pd bimetallic NP catalyst modified with $\mathrm{Sn} / \mathrm{SnO}_{\mathrm{x}}$. First, the mesostructured cellular foam silica (MCF) supported $\mathrm{Au}-\mathrm{Pd}$ NP catalyst (AP-ox) was prepared by a one-pot method. ${ }^{8}$ Second, the $\mathrm{SnO}_{\mathrm{x}}$ was deposited on the surface of Au-Pd NPs to obtain the $\mathrm{SnO}_{\mathrm{x}} @ \mathrm{AP}-\mathrm{ox}$ catalysts. The results showed that the $\mathrm{SnOx}$ significantly enhanced the benzaldehyde yield thus broking the dilemma between the high activity and high selectivity of Au-Pd NPs catalyst. The role of $\mathrm{SnO}_{\mathrm{x}}$ in modulating the catalyst performance was approved experimentally and theoretically.

\section{EXPERIMENTAL SECTION}

2.1. Chemicals. $\mathrm{HAuCl}_{4} \cdot \mathrm{xH}_{2} \mathrm{O}$ (Sinopharm Chemical), $\mathrm{PdCl}_{2}$ (Sinopharm Chemical), $\mathrm{SnCl}_{2} \cdot \mathrm{H}_{2} \mathrm{O}$ (Sinopharm Chemical), tetraethyl orthosilicate (TEOS, 98\%, Sinopharm Chemical), triblock co-polymer $\mathrm{PEO}_{20} \mathrm{PPO}_{70} \mathrm{PEO}_{20}$ (P123, Aldrich), mercaptopropyltrimethoxysilane (MPTMS, 97\%, Aldrich), 1,3,5-trimethylbenzene (99\%, Sinopharm Chemical), hydrochloric acid (37\%, Sinopharm Chemical), benzyl alcohol (99.99\%, Sinopharm Chemical), benzaldehyde (99.99\%, Sinopharm Chemical), benzoic acid (99.99\%, Sinopharm Chemical) and absolute ethanol (99.98\%, Sinopharm Chemical) were used as received without further purification. 
2.2. Preparation of Unmodified Catalysts. Supported Au-Pd NP catalyst was prepared following the procedure reported in our previous work. ${ }^{8}$ In a typical synthesis, $8.0 \mathrm{~g}$ of $\mathrm{P} 123$ was dissolved in $60 \mathrm{~mL}$ deionized water, followed by introduction of $20 \mathrm{~mL}$ of concentrated hydrochloric acid (37\%) at room temperature. Then, $8 \mathrm{~g}$ of 1,3,5-trimethylbenzene was added into the clear solution as a pore swelling agent and stirred at $38{ }^{\circ} \mathrm{C}$ for $2 \mathrm{~h}$, followed by the dropwise addition of 18.4 $\mathrm{g}$ TEOS and $1.14 \mathrm{~g}$ MPTMS into the mixture. Finally, the $\mathrm{HAuCl}_{4}$ and $\mathrm{PdCl}_{2}$ solutions were added into the synthesis mixtures. After stirring at $38{ }^{\circ} \mathrm{C}$ for $24 \mathrm{~h}$, the mixtures were transferred to a Teflon-lined stainless-steel autoclave to undergo a hydrothermal treatment at $100{ }^{\circ} \mathrm{C}$ for $24 \mathrm{~h}$. The obtained solids were purified with deionized water, dried at $80{ }^{\circ} \mathrm{C}$ overnight, and eventually calcined in air at $550{ }^{\circ} \mathrm{C}$ for $6 \mathrm{~h}$ to remove the templating and coupling agent. Catalysts with a total noble metal $(\mathrm{Au}+\mathrm{Pd})$ loading of 0.75 wt.\% with an Au loading of 0.25 wt.\% and a Pd loading of 0.5 wt. $\%$ were abbreviated as AP-ox and the reduced samples were denoted as AP- $\mathrm{H}_{2}$. Monometallic catalysts $\mathrm{Au}-\mathrm{ox}$ with an $\mathrm{Au}$ weight ratio of $0.25 \%$ and $\mathrm{Pd}$-ox with a $\mathrm{Pd}$ weight ratio of $0.5 \%$ were prepared as references. The catalysts $2 \mathrm{Pd}$-ox with a $\mathrm{Pd}$ weight ratio of $1.0 \%$ and $2 \mathrm{AP}-\mathrm{ox}$ with $\mathrm{Pd}$ and $\mathrm{Au}$ weight ratio of $1.0 \%$, respectively, were also prepared for comparison purpose.

2.2.1 Preparation of $\mathrm{SnO}_{\mathbf{x}} @$ AP Catalysts. $2 \mathrm{~g}$ of AP-ox solid was dispersed in a stannous chloride solution and stirred at room temperature for $4 \mathrm{~h}$ until a slurry was formed. The obtained slurry was dried at $100{ }^{\circ} \mathrm{C}$ for $12 \mathrm{~h}$ and finally calcined at 300 ${ }^{\circ} \mathrm{C}$ for $4 \mathrm{~h}$ under air atmosphere. Different amounts of $\mathrm{SnO}_{\mathrm{x}}$ were introduced and the 
obtained catalysts were denoted as $y \mathrm{SnO}_{x} @ \mathrm{AP}-\mathrm{ox}$ ( $y$ represents the nominal weight percentage of $\mathrm{SnO}_{\mathrm{x}}$, such as $\left.0 \%, 0.2 \%, 0.5 \%, 1.0 \%, x=1 \sim 2\right)$. These catalysts were reduced at $300{ }^{\circ} \mathrm{C}$ for $2 \mathrm{~h}$ under $\mathrm{H}_{2}$ atmosphere to investigate the effect of reduction on the catalytic performance; the obtained catalysts were denoted as $y \mathrm{SnO}_{x} @ \mathrm{AP}-\mathrm{H}_{2}$.

For comparison, catalysts $1 \% \mathrm{SnO}_{\mathrm{x}} @ 2 \mathrm{Pd}-\mathrm{ox}$ and 1\% $\mathrm{SnO}_{\mathrm{x}} @ 2 \mathrm{AP}-\mathrm{ox}$ with higher noble metal loadings were prepared following the same procedure and reduced under $\mathrm{H}_{2}$ atmosphere to obtain samples $1 \% \mathrm{SnO}_{\mathrm{x}} @ 2 \mathrm{Pd}-\mathrm{H}_{2}$ and $1 \% \mathrm{SnO}_{\mathrm{x}} @ 2 \mathrm{AP}-\mathrm{H}_{2}$, respectively.

2.3 Characterization. $\mathrm{N}_{2}$ adsorption/desorption was carried out to analyze the textural properties of catalysts after degassing at $300{ }^{\circ} \mathrm{C}$ for $4 \mathrm{~h}$ under vacuum using an automatic volumetric sorption analyzer (Micromeritics, TriStar 3000). X-ray powder diffraction (XRD) patterns of catalysts were recorded on a X'Pert PRO MPD system (Dutch company Panaco) with a $\mathrm{Cu} K \alpha$ radiation $(\lambda=0.15418 \mathrm{~nm})$ at $35 \mathrm{kV}$ and $40 \mathrm{~mA}$. High angle annular dark field (HAADF) images and X-ray energy dispersive spectroscopy (XEDS) of the catalysts were obtained using a scanning transmission electron microscope (STEM) (JEOL JEM-2100F) with an acceleration voltage of $200 \mathrm{kV}$. HAADF images of nanoparticles were collected on HITACHI HF5000 field emission transmission electron microscope equipped with a spherical aberration corrector (AC-TEM) and energy dispersive spectroscopy (EDS) from Oxford operated at $200 \mathrm{kV}$. Actual noble metal loadings in the catalysts were determined by inductively coupled plasma optical emission spectroscopy (ICP-OES) using a VISTA-MPX Varian system. The solid ultraviolet-visible (UV-vis) spectra of 
catalysts were collected by a Hitachi U-4100 UV-vis-NIR spectrophotometer using $\mathrm{BaSO}_{4}$ as an internal reference. The diffuse reflectance spectra from 350 to $800 \mathrm{~nm}$ were recorded. The surface chemical properties of the catalysts were analyzed using a K-alpha X-ray spectrometer (XPS) manufactured by Thermo Fisher Scientific. Taking the $\mathrm{Al}$ electrode as the anode, the electron kinetic energy was $1486.6 \mathrm{eV}$. The spectra were calibrated with $\mathrm{C} 1 \mathrm{~s}$ binding energy $(284.5 \mathrm{eV})$ as a calibration binding energy (BE) reference. In situ diffuse reflectance infrared Fourier transform spectroscopy (DRIFTS) of $\mathrm{CO}$ adsorption on the fresh catalysts (pretreated in $\mathrm{H}_{2}$ at $573 \mathrm{~K}$ at a flow rate of $20 \mathrm{~mL} \mathrm{~min}^{-1}$ for $60 \mathrm{~min}$, cooled down to $303 \mathrm{~K}$ and purged with He for 30 min) was conducted in a high-temperature diffuse reflection reaction cell (PIKE). The spectra were recorded on a BRUKER VERTEX70V FT-IR spectrometer at room temperature with a resolution of $4 \mathrm{~cm}^{-1}$. $\mathrm{H}_{2}$-temperature programmed reduction $\left(\mathrm{H}_{2}\right.$-TPR) experiments were conducted on a chemisorption apparatus (Micromeritics AutoChem II 2920). Typically, the sample (100 mg) was pre-treated at $300{ }^{\circ} \mathrm{C}$ for $1 \mathrm{~h}$ under an Ar stream (30 mL/min). Afterwards, the system was cooled to $50{ }^{\circ} \mathrm{C}$, and then a 10 vol\% $\mathrm{H}_{2} / \mathrm{Ar}$ stream $(30 \mathrm{~mL} / \mathrm{min})$ was introduced. The temperature was raised linearly from $100{ }^{\circ} \mathrm{C}$ to $800{ }^{\circ} \mathrm{C}$ at a rate of $10{ }^{\circ} \mathrm{C} / \mathrm{min}$, and the signal was recorded by a thermal conductivity detector (TCD).

2.4 Selective Oxidation of Benzyl Alcohol. The selective oxidation of benzyl alcohol was carried out in a $100 \mathrm{~mL}$ autoclave with a polytetrafluoroethylene liner (Model: SLM100, Beijing Easychem Science and Technology Development Company, China). Typically, $10.8 \mathrm{~g}$ of benzyl alcohol and $50 \mathrm{mg}$ of solid catalyst 
were charged into the reaction vessel. After purging with $\mathrm{O}_{2}$ for 3 times, the temperature was raised to $110{ }^{\circ} \mathrm{C}$ and the $\mathrm{O}_{2}$ pressure was maintained at $0.8 \mathrm{MPa}$ for 2 $\mathrm{h}$ under stirring. Then, the products were separated and analyzed using a gas chromatograph (Agilent 6870) equipped with a FID detector and a DB-1 column $(30 * 0.32 * 0.25)$. The turnover frequency (TOF) was calculated based on the moles of benzyl alcohol converted per mole of noble metals $(\mathrm{Au}+\mathrm{Pd})$ per hour.

2.5 Theoretical Calculation.The spin-polarized density functional theory (DFT) calculations were implemented using the $\mathrm{DMol}^{3}$ program of Materials Studio 2018 software package. ${ }^{24-25}$ The exchange-correlation term was described within the general gradient approximation developed by Perdew, Burke, and Ernzerhof $\left(\right.$ GGA-PBE) ${ }^{26}$ Particularly, Grimme's PBE+D2 method was used to correct the long-range dispersion forces, ${ }^{27}$ which shows a comparable reliability with the PBE0 hybrid XC functional including an ab initio Van der Waals correction. ${ }^{28}$ The ion cores of metal atoms were treated with the density functional semicore pseudopotential (DSPP), while the valence electron functions were represented by the localized double-numerical basis with polarization (DNP) function. The transition state structures were located by using the linear synchronous transition/quadratic synchronous transit method, ${ }^{29}$ confirmed by the frequency calculations. A real-space global orbital cutoff of $4.9 \AA$ was adopted to keep the balance between high quality of results and high computational cost. The convergence tolerances for energy change, max force, and displacement were $1 \times 10^{-5} \mathrm{Ha}, 2 \times 10^{-3} \mathrm{Ha} \AA^{-1}$, and $5 \times 10^{-3} \AA$, respectively. According to the experimental results, a homogeneous $\mathrm{Pd}_{3} \mathrm{Au}$ alloy with 
a $\mathrm{Pd}-\mathrm{Au}$ atomic ratio of 3:1 was selected as the palladium-gold alloy model, and a stable close-packed (111) surface was chosen as the model surface $\left(\operatorname{Pd}_{3} \mathrm{Au}(111)\right)$. The $\mathrm{Pd}_{3} \mathrm{Au}(111)$ model was established by a four-layers periodic slab model with a $\mathrm{p}(4 \times 4)$ unit cell and a vacuum region of $15 \AA$. The $\operatorname{Pd}_{3} \operatorname{Sn}_{3} \mathrm{Au}(111)$ model was created by replacing the $\mathrm{Pd}$ atoms on the top surface layer of $\mathrm{Pd}_{3} \mathrm{Au}(111)$ with $\mathrm{Sn}$ atoms in a ratio of $1: 1$, and the other bottom three layers still maintained as $\operatorname{Pd}_{3} \mathrm{Au}$. The $\mathrm{Pd}_{3} \mathrm{Au}(111)$ surface was covered by a layer of $\mathrm{Sn}, \mathrm{SnO}$, and $\mathrm{SnO}_{2}$ species to form $\mathrm{Sn} / \mathrm{Pd}_{3} \mathrm{Au}(111), \mathrm{SnO} / \mathrm{Pd}_{3} \mathrm{Au}(111), \mathrm{SnO}_{2} / \mathrm{Pd}_{3} \mathrm{Au}(111)$ models, respectively. Sn, $\mathrm{SnO}$, and $\mathrm{SnO}_{2}$ species were doped on the $\mathrm{Pd}_{3} \mathrm{Au}(111)$ surface to form $\mathrm{Sn} / \mathrm{Pd}_{3} \mathrm{Au}(111)$, $\mathrm{SnO} / \mathrm{Pd}_{3} \mathrm{Au}(111), \quad \mathrm{SnO}_{2} / \mathrm{Pd}_{3} \mathrm{Au}(111)$ models, respectively. In $\mathrm{Sn} / \mathrm{Pd}_{3} \mathrm{Au}(111)$, $\mathrm{SnO} / \mathrm{Pd}_{3} \mathrm{Au}(111), \mathrm{SnO}_{2} / \mathrm{Pd}_{3} \mathrm{Au}(111)$, the number of $\mathrm{Sn}, \mathrm{SnO}$, and $\mathrm{SnO}_{2}$ units was half of the atom number of the top-layer $\mathrm{Pd}_{3} \mathrm{Au}(111)$, where the unit cell contained $8 \mathrm{Sn}$, $\mathrm{SnO}$, and $\mathrm{SnO}_{2}$ units, respectively. In the slab calculations, the atoms in the two bottom layers were fixed in their bulk positions, but all other atoms were allowed to be fully relaxed.

The adsorption energy $\left(E_{\mathrm{ads}}\right)$ of an adsorbate on catalyst surfaces was defined as

$$
E_{\text {ads }}=E_{\text {adsorbate/substrate }}-\left(E_{\text {adsorbate }}+E_{\text {substrate }}\right),
$$

where $E_{\text {adsorbate/substrate }}$ and $E_{\text {substrate }}$ correspond to the total energy of the catalyst substrate with and without an adsorbed molecule, respectively, while $E_{\text {adsorbate }}$ represents the energy of the free adsorbate.

\section{RESULTS AND DISCUSSION}


3.1 Catalyst Characterization. $\mathrm{N}_{2}$ adsorption-desorption isotherms and pore size distribution curves of catalysts $y \mathrm{SnO}_{\mathrm{x}} @ \mathrm{AP}-\mathrm{ox}\left(\mathrm{H}_{2}\right)$ are shown in Figure S1A, B and the results are summarized in Table 1. A typical type IV isotherm was measured on all catalysts, which contains a $\mathrm{H}-2$ hysteresis loop, indicating an ink-bottle mesoporous structure. Reference catalysts Pd-ox and AP-ox exhibited a high specific surface area $\left(\sim 800 \mathrm{~m}^{2} / \mathrm{g}\right)$ and a large pore volume $\left(1.8 \sim 2.3 \mathrm{~cm}^{3} / \mathrm{g}\right)$. A small amount of $\mathrm{SnO}_{\mathrm{x}}$ introduced in catalysts $0.2 \% \mathrm{SnO}_{\mathrm{x}} @ \mathrm{AP}$-ox and $0.5 \% \mathrm{SnO}_{\mathrm{x}} @ \mathrm{AP}-\mathrm{ox}$ leads to a slight decrease of the specific surface area $\left(700-750 \mathrm{~m}^{2} / \mathrm{g}\right)$. While the specific surface area of catalyst $1.0 \% \mathrm{SnO}_{\mathrm{x}} @ \mathrm{AP}-\mathrm{ox}$ significantly decreases to $\sim 650 \mathrm{~m}^{2} / \mathrm{g}$ when $1 \mathrm{wt} . \%$ of $\mathrm{SnO}_{\mathrm{x}}$ was added. The average pore diameter increased from $5.6 \mathrm{~nm}$ for catalyst $0.2 \% \mathrm{SnO}_{\mathrm{x}} @ \mathrm{AP}-\mathrm{ox}$ to $7.8 \mathrm{~nm}$ for catalyst $1.0 \% \mathrm{SnO}_{\mathrm{x}} @ \mathrm{AP}-\mathrm{ox}$. The decrease of specific surface area and pore volume on catalyst $1.0 \% \mathrm{SnO}_{\mathrm{x}} @ \mathrm{AP}-\mathrm{ox}$ was attributed to the partial blocking of small pores after introducing a relatively large amount of $\mathrm{SnO}_{\mathrm{x}}$. 
Table 1. Physical Properties of Catalysts.

\begin{tabular}{|c|c|c|c|c|c|c|}
\hline \multirow[b]{2}{*}{ Catalysts } & \multicolumn{3}{|c|}{ Metal loading $^{\mathrm{a}}(w t . \%)$} & \multirow{2}{*}{$\begin{array}{l}\mathrm{S}_{\mathrm{BET}} \\
\left(\mathrm{m}^{2} / \mathrm{g}\right)\end{array}$} & \multirow{2}{*}{$\begin{array}{l}\text { Pore } \\
\text { volume } \\
\left(\mathrm{cm}^{3} / \mathrm{g}\right)\end{array}$} & \multirow{2}{*}{$\begin{array}{c}\text { Pore } \\
\text { diamete } \\
\text { (nm) }\end{array}$} \\
\hline & $\mathrm{Au}$ & $\mathrm{Pd}$ & $\mathrm{Sn}$ & & & \\
\hline Pd -ox & 0 & 0.5 & 0 & 839 & 1.8 & 5.7 \\
\hline AP-ox & 0.25 & 0.49 & 0 & 791 & 2.3 & 9.6 \\
\hline $0.2 \% \mathrm{SnO}_{\mathrm{x}} @ \mathrm{AP}-\mathrm{ox}$ & 0.24 & 0.50 & 0.18 & 698 & 1.6 & 5.6 \\
\hline $0.5 \% \mathrm{SnO}_{\mathrm{x}} @ \mathrm{AP}-\mathrm{ox}$ & 0.24 & 0.49 & 0.44 & 747 & 1.7 & 5.6 \\
\hline $1.0 \% \mathrm{SnO}_{\mathrm{x}} @ \mathrm{AP}-\mathrm{ox}$ & 0.25 & 0.49 & 0.88 & 650 & 1.6 & 7.8 \\
\hline $0.5 \% \mathrm{SnO}_{\mathrm{x}} @ \mathrm{AP}-\mathrm{H}_{2}$ & 0.24 & 0.48 & 0.44 & 653 & 1.6 & 5.6 \\
\hline
\end{tabular}

${ }^{a}$ The metal loading was evaluated by ICP-OES. $S_{B E T}$, surface area calculated by the BET method.

$V_{\text {total }}$, total pore volume calculated at $P / P_{o}=0.998$. Pore diameter calculated from the adsorption branch using BJH method. 


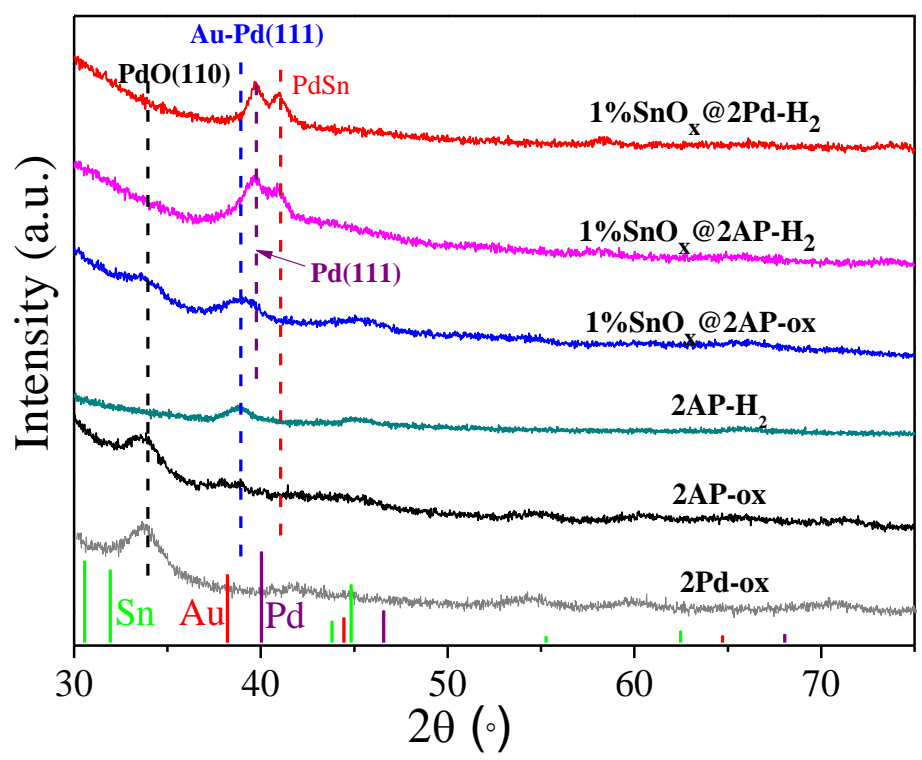

Figure 1. XRD patterns of catalysts 2Pd-ox, 2AP-ox, 2AP- $\mathrm{H}_{2}, 1 \% \mathrm{SnO}_{\mathrm{x}} @ 2 \mathrm{Pd}-\mathrm{ox}$, $1 \% \mathrm{SnO}_{\mathrm{x}} @ 2 \mathrm{AP}-\mathrm{ox}$ and $1 \% \mathrm{SnO}_{\mathrm{x}} @ 2 \mathrm{AP}-\mathrm{H}_{2}$.

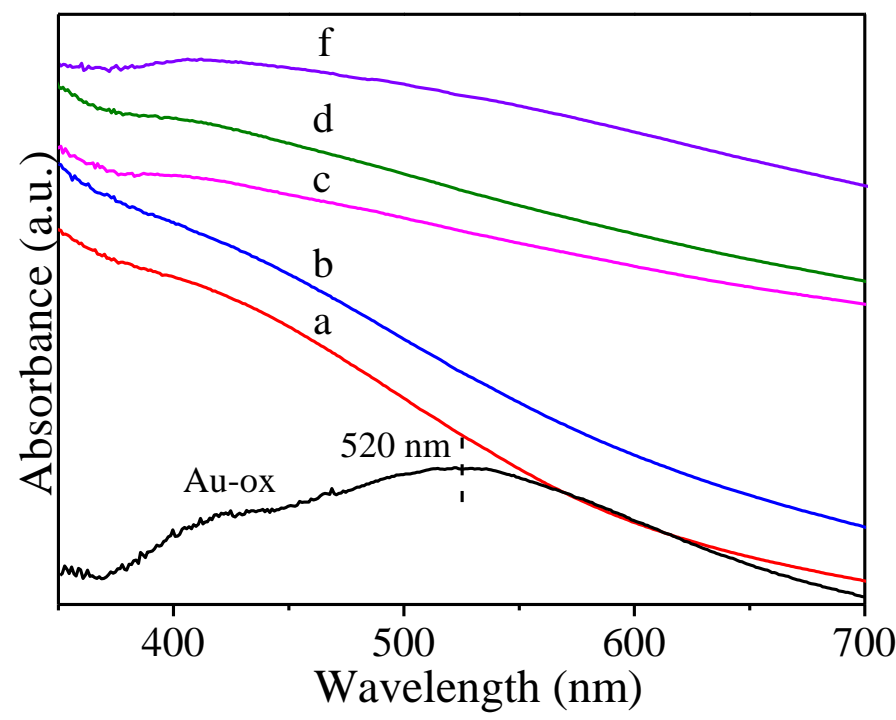

Figure 2. Solid UV-vis spectra of catalysts: (a) Pd-ox, (b) AP-ox, (c)
$0.2 \% \mathrm{SnO}_{\mathrm{x}} @ \mathrm{AP}-\mathrm{ox}$
(d) $0.5 \% \mathrm{SnO}_{\mathrm{x}} @ \mathrm{AP}-\mathrm{ox}$,
(e) $1.0 \% \mathrm{SnO}_{\mathrm{x}} @ \mathrm{AP}-\mathrm{ox}$,

$0.5 \% \mathrm{SnOx} @ \mathrm{AP}-\mathrm{H}_{2}$.

Different amounts of $\mathrm{SnO}_{\mathrm{x}}$ were introduced into the bimetallic AP-ox catalysts with constant $\mathrm{Au}(\sim 0.25 w t . \%)$ and $\mathrm{Pd}(\sim 0.5 w t . \%)$ contents. The actual metal content was determined by ICP-OES and the results are summarized in Table 1 . The XRD 
patterns of catalysts in the range of $19.5-70.5^{\circ} 2 \theta$ reveal the weak diffraction peaks due to the presence of Pd, Au-Pd and PdO (Figure S1C). Catalysts with high metal loadings were prepared to clarify the peak positions of metals and oxides (Figure 1). Both 2Pd-ox and 2AP-ox catalysts contain a diffraction peak at $33.69^{\circ} 2 \theta$ corresponding to the PdO (110) (PDF\#06-0515). No reduction of the catalysts was carried out and therefore the $\mathrm{PdO}$ is present. ${ }^{8}$ After introducing the $\mathrm{SnO}_{\mathrm{x}}$ on catalyst $1 \% \mathrm{SnO}_{\mathrm{x}} @ 2 \mathrm{AP}-\mathrm{ox}$, the intensity of the characteristic $\mathrm{PdO}$ phase peak at $2 \theta=33.69^{\circ}$ was reduced. The peaks at $40.1^{\circ}$ and $46.6^{\circ} 2 \theta$ corresponding to (111) and (200) planes of cubic Pd (PDF\#65-2867) shifted to lower $38.9^{\circ}$ and $45.3^{\circ} 2 \theta$ for catalyst $1 \% \mathrm{SnO}_{\mathrm{x}} @ 2 \mathrm{AP}-\mathrm{ox}$, respectively, which was attributed to the formation of $\mathrm{Au}-\mathrm{Pd}(111)$ phase. ${ }^{30}$ This result is in accordance with XRD pattern of catalyst $2 \mathrm{AP}-\mathrm{H}_{2}$ shown in Figure 1. After reduction, two diffraction peaks at $39.9^{\circ}$ and $41.0^{\circ} 2 \theta$ were observed for catalyst $1 \% \mathrm{SnO}_{\mathrm{x}} @ 2 \mathrm{AP}-\mathrm{H}_{2}$, similar to the diffraction peaks detected for the $1 \% \mathrm{SnO}_{\mathrm{x}} @ 2 \mathrm{Pd}-\mathrm{H}_{2}$. The peak at $39.9^{\circ} 2 \theta$ can be assigned to the cubic $\mathrm{Pd}$ (111) plane $\left(40.1^{\circ}\right)$, while the peak at $41.0^{\circ} 2 \theta$ is due to $\mathrm{PdSn}(111)$ phase. These results revealed that the $\mathrm{H}_{2}$ reduction treatment weakens the interactions between $\mathrm{Au}$ and $\mathrm{Pd}$ leading to the formation of Pd-Sn alloy. No obvious $\mathrm{Sn}$ or $\mathrm{SnO}_{\mathrm{x}}$ species were detected on these catalysts, implying either a good dispersion or amorphous Sn species. ${ }^{31}$ Concisely, Pd exists as $\mathrm{PdO}$ species on unpromoted catalysts 2Pd-ox and 2AP-ox, but partially as $\mathrm{Au}-\mathrm{Pd}$ alloy species on $\mathrm{SnO}_{\mathrm{x}}$ promoted $1 \% \mathrm{SnO}_{\mathrm{x}} @ 2 \mathrm{AP}-\mathrm{ox}$ catalyst. This phase variation indicated that the introduction of $\mathrm{SnO}_{\mathrm{x}}$ led to partial reduction of $\mathrm{PdO}$ and promoted the formation of the Au-Pd alloy, which is probably due to the electron 
transfer from $\mathrm{SnO}_{\mathrm{x}}$ to $\mathrm{PdO},{ }^{32-33}$ due to the lower electronegativity and stronger oxophilicity of Sn than Pd. ${ }^{34}$ As shown in Figure S1C, the same trend was observed for catalysts ySnO $\mathrm{S}_{\mathrm{x}} @ \mathrm{AP}-\mathrm{ox}\left(\mathrm{H}_{2}\right)$ with different $\mathrm{SnO}_{\mathrm{x}}$ concentrations; low intensity of the Bragg peaks is due to the low metal loadings.

The UV-vis spectra of catalysts $y \mathrm{SnO}_{\mathrm{x}} @ \mathrm{AP}-\mathrm{ox}$ and $y \mathrm{SnO}_{\mathrm{x}} @ \mathrm{AP}-\mathrm{H}_{2}$ are shown in Figure 2 and Figure S2, respectively. A broad peak at around $520 \mathrm{~nm}$ for monometallic catalyst Au-ox is attributed to the surface plasma resonance (SPR) of $\mathrm{Au}^{0}$ NPs. ${ }^{35}$ However, on bimetallic AP-ox and $\mathrm{SnO}_{\mathrm{x}}$ promoted $y \mathrm{SnO}_{\mathrm{x}} @ \mathrm{AP}-\mathrm{ox}$ catalysts the characteristic peak of Au NPs is not observed, indicating the formation of Au-Pd alloy NPs on these catalysts (Figure 1) and also Au was no longer present as a pure metallic particle. ${ }^{1}$ Even after $\mathrm{H}_{2}$ reduction at $300{ }^{\circ} \mathrm{C}\left(y \mathrm{SnO}_{\mathrm{x}} @ \mathrm{AP}-\mathrm{H}_{2}\right)$, no bands corresponding to the Au NPs were observed in the UV-vis spectra, revealing that $\mathrm{Au}$ still exists as alloy species (Au-Pd-Sn) (Figure S2). Further elevated reduction temperature to $400{ }^{\circ} \mathrm{C}$ and $500{ }^{\circ} \mathrm{C}$ did not lead to obvious Au phase formation (Figure S3), no SPR of Au NPs (clusters) were detected even after reduction at $500{ }^{\circ} \mathrm{C}$ for $2 \mathrm{~h}$. Based on the above results, we could conclude that $\mathrm{H}_{2}$ reduction weakens the interaction between $\mathrm{Au}$ and $\mathrm{Pd}$ and no pure $\mathrm{Au}$ phase was present, implying that probably Au-Pd-Sn alloy is the dominant phase in the sample. 


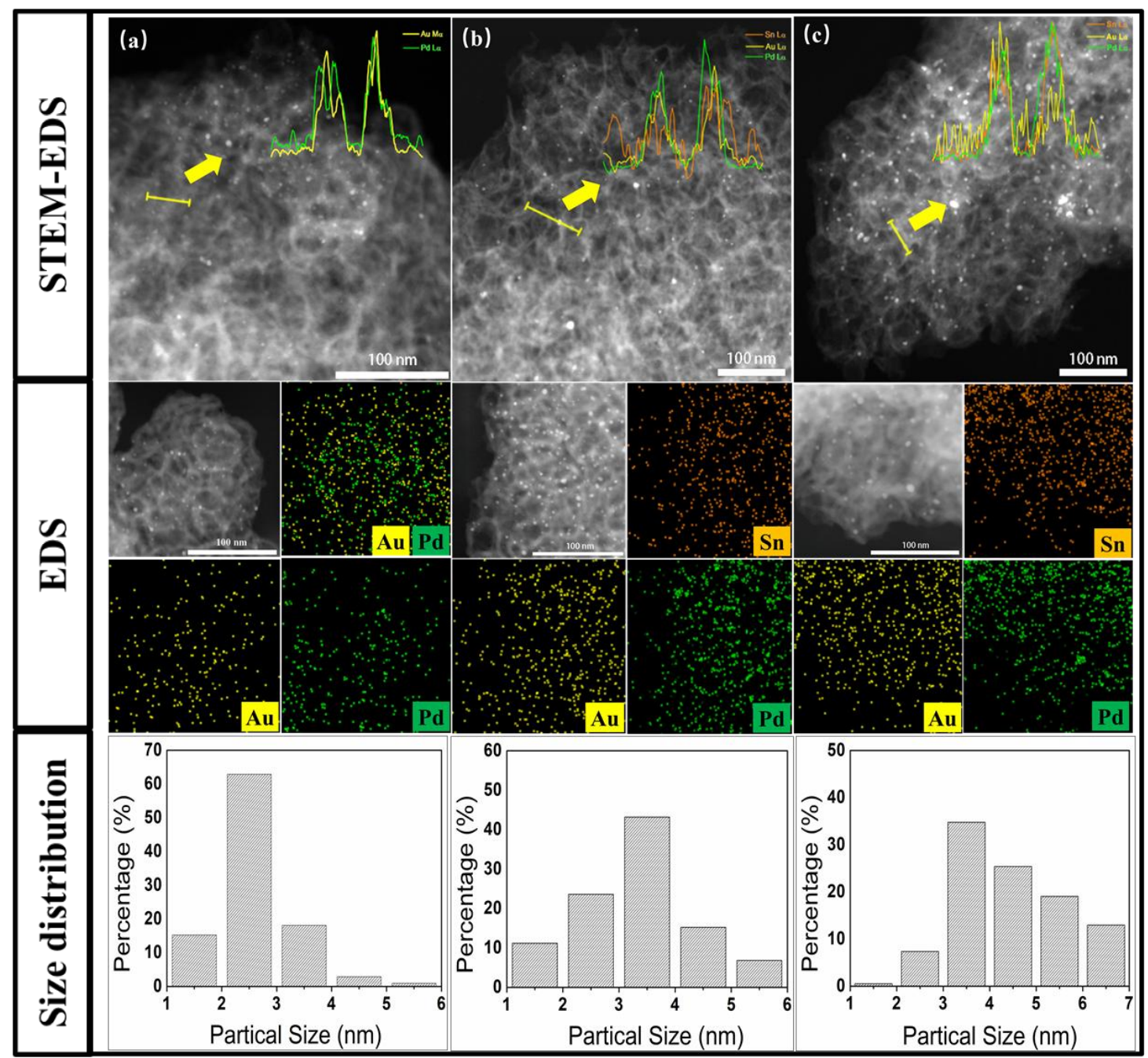

Figure 3. STEM-HAADF images of catalysts (Insets: energy dispersive line scan across NPs using the Au-M, Pd-L and Sn-L X-rays) and the corresponding EDS spectral maps of $\mathrm{Au}$ (yellow), Pd (green) and Sn (orange) and particle size distribution histograms of catalysts (a) AP-ox, (b) $0.5 \% \mathrm{SnO}_{\mathrm{x}} @ \mathrm{AP}-\mathrm{ox}$ and (c) $0.5 \% \mathrm{SnO}_{\mathrm{x}} @ \mathrm{AP}-\mathrm{H}_{2}$

Figure 3 shows representative STEM-HAADF images and EDS spectral maps, and the histograms of the particle size distribution of catalysts AP-ox, $0.5 \% \mathrm{SnO}_{\mathrm{x}} @ \mathrm{AP}-\mathrm{ox}$ and $0.5 \% \mathrm{SnO}_{\mathrm{x}} @ \mathrm{AP}-\mathrm{H}_{2}$. The size effect of the NP catalyst and the distribution of metal elements play important roles in their catalytic performance. ${ }^{23,} 36$ The representative STEM-HAADF images and the corresponding EDS spectral maps of 
catalyst AP-ox indicated the presence of well-dispersed $\mathrm{Au}$ and $\mathrm{Pd}$ on the MCF support. Moreover, the energy dispersive line scan across NPs revealed the consistent dispersion of these two elements, indicating the formation of Au-Pd nano-alloys, which is in agreement with the UV-vis results. After introducing $\mathrm{SnO}_{\mathrm{x}}$, a slight increase of NPs size (2-6nm) was observed on catalyst $0.5 \% \mathrm{SnO}_{\mathrm{x}} @ \mathrm{AP}-\mathrm{ox}$ comparing with that $(2-4 \mathrm{~nm})$ on catalyst AP-ox, which was probably due to the dispersion of $\mathrm{SnO}_{\mathrm{x}}$ on Au-Pd NPs. The energy dispersive line scan across the NPs indicated that the dispersion of $\mathrm{Sn}$ atoms was identical to that of $\mathrm{Au}-\mathrm{Pd} .^{37}$ After the reduction, the intensity of $\mathrm{Sn}$ signal was significantly enhanced on catalyst $0.5 \% \mathrm{SnO}_{\mathrm{x}} @ \mathrm{AP}-\mathrm{H}_{2}$ and this result is indicating the aggregation of $\mathrm{Sn}$ on Au-Pd NPs and formation of $\mathrm{Au}-\mathrm{Pd}-\mathrm{Sn}$ NPs with uniform composition. The introduction of $\mathrm{SnO}_{\mathrm{x}}$ resulted in a slight increase of metal particle size for catalyst $0.5 \% \mathrm{SnO}_{\mathrm{x}} @ \mathrm{AP}-\mathrm{ox}$ and a further increase of particle size on reduced catalyst $0.5 \% \mathrm{SnO}_{\mathrm{x}} @ \mathrm{AP}-\mathrm{H}_{2}(3-7 \mathrm{~nm})$, which is probably due to the reduction process leading to enhanced interaction between $\mathrm{Au}-\mathrm{Pd}$ NPs and Sn and aggregation into larger NPs.

To further study the chemical composition of alloy NPs before and after $\mathrm{H}_{2}$ reduction, the high-resolution HAADF images and corresponding element analysis spectra of catalysts $0.5 \% \mathrm{SnO}_{\mathrm{x}} @ \mathrm{AP}-\mathrm{ox}$ and $0.5 \% \mathrm{SnO}_{\mathrm{x}} @ \mathrm{AP}-\mathrm{H}_{2}$ were recorded by AC-TEM (Figure 4). Energy-dispersive line-scanning spectra (Figure 4b) show a much higher signal intensity of $\mathrm{Au}$ and $\mathrm{Pd}$ than that of $\mathrm{Sn}$ on catalyst $0.5 \% \mathrm{SnO}_{\mathrm{x}} @ \mathrm{AP}-\mathrm{ox}$. EDS elemental mapping (Figure 4d-f) further verified the homogenous dispersion of $\mathrm{Au}$ and $\mathrm{Pd}$, confirming the formation of Au-Pd alloy NPs. 
Correlating the line-scanning spectra shown in Figure 4b with EDS mapping of Sn element (Figure 4f), it can be concluded that $\mathrm{SnO}_{\mathrm{x}}$ was successfully deposited on Au-Pd NPs of the un-reduced catalyst 0.5\% $\mathrm{SnO}_{\mathrm{x}} @ \mathrm{AP}-\mathrm{ox}$. The Sn element evenly distributed on the surface of catalyst $0.5 \% \mathrm{SnO}_{\mathrm{x}} @ \mathrm{AP}$-ox (Figure $4 \mathrm{~b}$ ). By contrast, an obvious accumulation of Sn element on Au-Pd alloy NPs was observed through line scan (Figure 4b') and elemental mapping (Figure 4f') on the $\mathrm{H}_{2}$-reduced catalyst $0.5 \% \mathrm{SnO}_{\mathrm{x}} @ \mathrm{AP}-\mathrm{H}_{2}$, and the nanoparticles were morphologically structured with an Au-Pd rich core and a Sn-rich shell. These results revealed the structure reconstruction of alloy NPs and presence of strong interaction between Au-Pd NPs and $\mathrm{Sn}$ after $\mathrm{H}_{2}$ reduction. These observations are in line with the XRD and TEM results. 


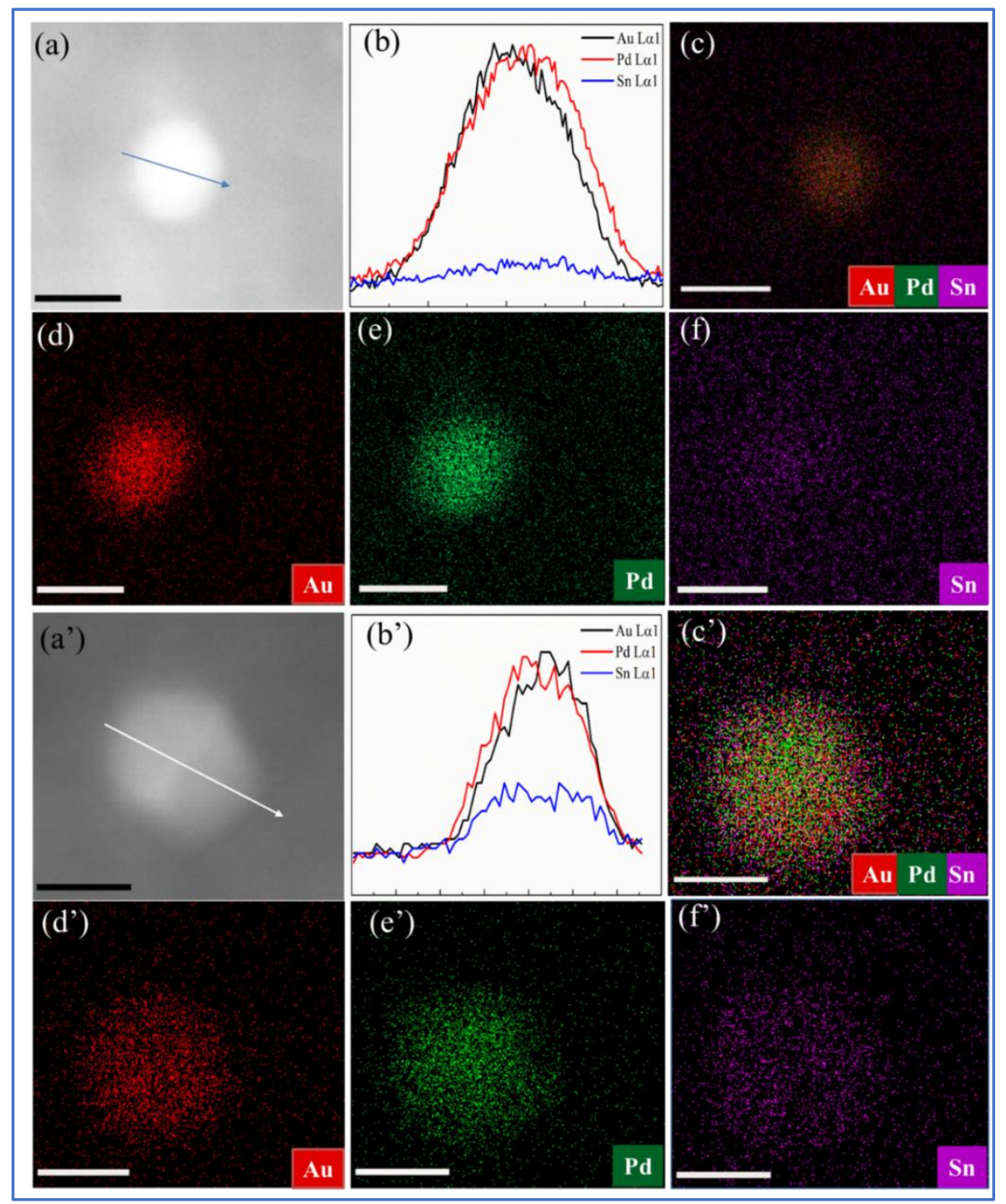

Figure 4. High resolution HAADF-STEM images with energy-dispersive line-scans of a single nanoparticle and elemental maps of $\mathrm{Au}, \mathrm{Pd}, \mathrm{Sn}$ and merged (Au-Pd-Sn) images of catalysts $0.5 \% \mathrm{SnO}_{\mathrm{x}} @ \mathrm{AP}-\mathrm{ox}(\mathrm{a}-\mathrm{f})$ and $0.5 \% \mathrm{SnO}_{\mathrm{x}} @ \mathrm{AP}-\mathrm{H}_{2}\left(\mathrm{a}^{\prime}-\mathrm{f}^{\prime}\right)$. Scale bar, $\mathrm{M}=5 \mathrm{~nm}$. 

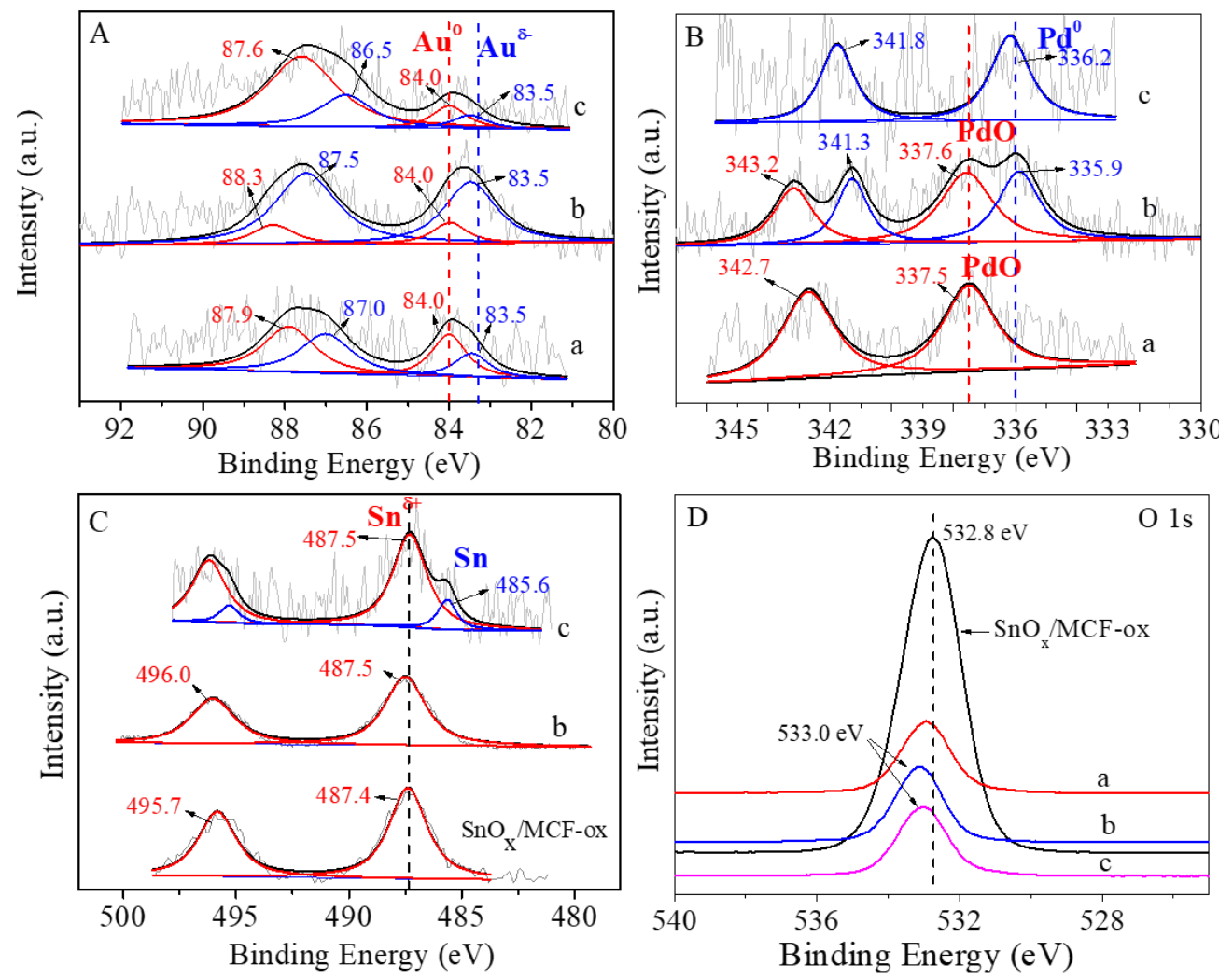

Figure 5. Au 4f XPS spectra (A), Pd 3d XPS spectra (B), Sn 3d XPS spectra (C) and O 1s XPS spectra (D) of catalysts: (a) AP-ox, (b) $0.5 \% \mathrm{SnO}_{\mathrm{x}} @ \mathrm{AP}-\mathrm{ox}$, (c) $0.5 \% \mathrm{SnO}_{\mathrm{x}} @ \mathrm{AP}-\mathrm{H}_{2}$ and a reference sample $1 \% \mathrm{SnO}_{\mathrm{x}} / \mathrm{MCF}-\mathrm{ox}$.

The XPS spectra of Au 4f, Pd 3d, Sn 3d, and O 1s are shown in Figure 5A-5D and the detailed surface states of elements are summarized in Table 2. The XPS spectra of $\mathrm{Au} 4 \mathrm{f}$ indicated the presence of two types of $\mathrm{Au}$ species $\left(\mathrm{Au}^{\delta-}\right.$ and $\left.\mathrm{Au}^{0}\right)$ on the catalysts. $^{38-39}$ The two characteristic peaks with binding energies (BE) of $84.0 \mathrm{eV}$ $\left(\mathrm{Au} 4 f_{7 / 2}\right)$ and $87.9 \mathrm{eV}\left(\mathrm{Au} 4 f_{5 / 2}\right)$ were observed on the bimetallic catalyst AP-ox, corresponding to the typical $\mathrm{Au}^{0}$ species. ${ }^{40}$ While the other two peaks with BEs of $83.5 \mathrm{eV}$ and $87.0 \mathrm{eV}$ are attributed to the presence of negatively charged $\mathrm{Au}^{\delta-}$ species. ${ }^{41}$ The formation of $\mathrm{Au}^{\delta-}$ species on bimetallic catalysts was due to the alloying effect of $\mathrm{Au}$ and $\mathrm{Pd}$, the electrons can easily transfer from $\mathrm{Pd}$ to $\mathrm{Au}$ to form 
negatively charged $\mathrm{Au}^{\delta-} \cdot{ }^{42}$ These four peaks were also observed on catalyst $0.5 \% \mathrm{SnO}_{\mathrm{x}} @ \mathrm{AP}-\mathrm{ox}$, indicating the existence of $\mathrm{Au}^{0}$ and $\mathrm{Au}^{\delta-}$ species, ${ }^{40-41}$ however, the ratio of surface $\mathrm{Au}^{\delta-} / \mathrm{Au}^{0}$ changed drastically from 0.6 for catalyst $\mathrm{AP}-\mathrm{ox}$ to 4.5 for catalyst $0.5 \% \mathrm{SnO}_{\mathrm{x}} @ \mathrm{AP}-\mathrm{ox}$. The low surface $\mathrm{Au}^{\delta-}$ content for catalyst AP-ox was due to the presence of surface PdO species as shown by XRD; the Au cannot alloy with PdO. ${ }^{11}$ Whereas the introduction of $\mathrm{SnO}_{\mathrm{x}}$ promoted the reduction of $\mathrm{PdO}$ and formation of Au-Pd alloy NPs and increase the amount of surface $\mathrm{Au}^{\delta-}$ species. On the reduced catalyst $0.5 \% \mathrm{SnO}_{\mathrm{x}} @ \mathrm{AP}-\mathrm{H}_{2}$, the $\mathrm{Au}^{\delta-} / \mathrm{Au}^{0}$ ratio decreased to 1.7 due to the partial reduction of $\mathrm{SnO}_{\mathrm{x}}$ to $\mathrm{Sn}$ and its alloying with $\mathrm{Au}-\mathrm{Pd}$ to form $\mathrm{Au}-\mathrm{Pd}-\mathrm{Sn}$ alloy NPs. The latest weakened the interaction between $\mathrm{Au}$ and $\mathrm{Pd}$ and resulted in a decrease of electron density of the Au surface.

For $3 \mathrm{~d}$ Pd XPS spectra contain the $3 \mathrm{~d}_{5 / 2}$ with $\mathrm{BE}$ of $335.5 \pm 0.3 \mathrm{eV}$ corresponds to $\mathrm{Pd}^{0}$ species $^{43-45}$ and the $3 \mathrm{~d}_{5 / 2}$ with $\mathrm{BE}$ of $337.5 \pm 0.3 \mathrm{eV}$ corresponds to $\mathrm{Pd}^{2+}(\mathrm{PdO})$ species. ${ }^{43-44}$ The Pd XPS spectrum (Figure 5B) of the AP-ox bimetallic catalyst contains a peak with $\mathrm{BE}$ of $337.5 \mathrm{eV}$ corresponding to $\mathrm{PdO}$ species. ${ }^{46}$ On $\mathrm{SnO}_{\mathrm{x}}$ promoted catalyst $\left(0.5 \% \mathrm{SnO}_{\mathrm{x}} @ \mathrm{AP}-\mathrm{ox}\right)$, two $\mathrm{Pd} 3 \mathrm{~d}_{5 / 2}$ characterization peaks with $\mathrm{BE}$ of $335.9 \mathrm{eV}$ and $337.6 \mathrm{eV}$ corresponding to $\mathrm{Pd}^{0}$ and $\mathrm{PdO}$, respectively, are present. ${ }^{46}$ These results are in accordance with the XRD data, revealing that the introduction of $\mathrm{SnO}_{\mathrm{x}}$ leads to a partial reduction of $\mathrm{PdO}$ to $\mathrm{Pd}^{0}$ species, which is due to the higher oxophilicity of $\mathrm{Sn}$ with lower electronegativity than the $\mathrm{Pd}(\mathrm{Sn}=1.96, \mathrm{Pd}=2.20) .{ }^{34} \mathrm{On}$ the $\mathrm{H}_{2}$ reduced catalyst $\left(0.5 \% \mathrm{SnO}_{\mathrm{x}} @ \mathrm{AP}-\mathrm{H}_{2}\right)$, the $\mathrm{Pd}^{0}$ species with $\mathrm{BE}$ of $336.2 \mathrm{eV},{ }^{47}$ 
with a slight positive shift $(0.3 \mathrm{eV})$ probably due to the strong interaction between $\mathrm{Sn}$ and Pd is observed.

The $\mathrm{Sn} 3 \mathrm{~d}$ XPS spectrum of the reference sample $\left(\mathrm{SnO}_{\mathrm{x}} / \mathrm{MCF}-\mathrm{ox}\right)$ contains peaks at $487.3 \mathrm{eV}\left(3 \mathrm{~d}_{5 / 2}\right)$ and $495.7 \mathrm{eV}\left(3 \mathrm{~d}_{3 / 2}\right)$ corresponding to the presence of $\mathrm{SnO}_{2}$ species (Figure 5C). The spectrum of catalyst $0.5 \% \mathrm{SnO}_{\mathrm{x}} @ \mathrm{AP}-\mathrm{ox}$ contains a peak slightly shifted to higher binding energy $(487.5 \mathrm{eV})$ confirming the presence of $\mathrm{SnO}_{2}$. This positive BE shift is generally attributed to the strong interaction between Au-Pd NPs and $\mathrm{SnO}_{2}$ in which an electron transfer from $\mathrm{SnO}_{2}$ to $\mathrm{Au}-\mathrm{Pd}$ occurred, ${ }^{48}$ resulting in partial reduction of $\mathrm{PdO}$ to $\mathrm{Pd}^{0}$ and formation of more surface $\mathrm{Au}^{\delta-}$ species as shown in Figure 5A, B. However, on the reduced catalyst $0.5 \% \mathrm{SnO}_{\mathrm{x}} @ \mathrm{AP}-\mathrm{H}_{2}$, typical $\mathrm{Sn}^{0}$ species with $\mathrm{BE}$ of $485.5 \mathrm{eV}$ were detected in addition to the $\mathrm{SnO}_{2}$, indicating that $\mathrm{SnO}_{2}$ was partially reduced under $\mathrm{H}_{2}$ at $300{ }^{\circ} \mathrm{C}$. In summary, electrons transfer from $\mathrm{SnO}_{2}$ species to $\mathrm{Au}$ and $\mathrm{Pd}$ on catalyst $0.5 \% \mathrm{SnO}_{\mathrm{x}} @ \mathrm{AP}$-ox, leading to the formation of Au-Pd alloy NPs was observed. As low-coordinated $\mathrm{Pd}^{0}$-enriched clusters are generally considered as active sites for benzyl alcohol oxidation, ${ }^{13,49}$ introducing $\mathrm{SnO}_{\mathrm{x}}$ to AP-ox catalyst increased the active sites of catalyst $0.5 \% \mathrm{SnO}_{\mathrm{x}} @ \mathrm{AP}-\mathrm{ox}$, which could cause an enhancement of catalytic activity for benzyl alcohol oxidation. After the reduction, the $\mathrm{PdO}$ was completely reduced to $\mathrm{Pd}^{0}$, and $\mathrm{SnO}_{\mathrm{x}}$ was partially reduced to Sn. The strong interaction between $\mathrm{Pd}$ and $\mathrm{Sn}$ species leaded to the formation of Au-Pd-Sn alloy as confirmed by correlating the UV-Vis and XRD results. The O $1 \mathrm{~s}$ XPS spectrum of sample $1 \% \mathrm{SnO}_{\mathrm{x}} / \mathrm{MCF}-\mathrm{ox}$ contains a lower energy band $(532.8 \mathrm{eV})$ implying that there are more electron-rich oxygen atoms near the 
surface of the metal oxide (Figure 5D). While for the $0.5 \% \mathrm{SnO}_{\mathrm{x}} @ \mathrm{AP}-\mathrm{ox}$, the binding energy shifted to higher value $(533.0 \mathrm{eV})$, indicating the weakening of surface metal oxygen (M-O) interactions.

Table 2. Surface Composition of Catalysts.

\begin{tabular}{|c|c|c|c|c|c|}
\hline \multirow{2}{*}{ Samples } & \multicolumn{2}{|r|}{ XPS } & \multicolumn{3}{|c|}{ XPS } \\
\hline & $\mathrm{Au}: \mathrm{Pd}: \mathrm{Sn}$ & $\mathrm{Au}: \mathrm{Pd}: \mathrm{Sn}$ & $A u^{\delta-}: A u^{0}$ & $\mathrm{Pd}^{0}: \mathrm{Pd}^{2+}$ & $\mathrm{Sn}^{0}: \mathrm{Sn}^{\delta+}$ \\
\hline AP-ox & 1: $3.6: 0$ & $1: 2.3: 0$ & $0.6: 1$ & $0: 1:$ & --- \\
\hline $0.5 \% \mathrm{SnO}_{\mathrm{x}} @ \mathrm{AP}-\mathrm{ox}$ & $1: 3.6: 2.8$ & $1: 6.0: 23.8$ & $4.5: 1$ & $1: 1.2$ & $0: 1$ \\
\hline $0.5 \% \mathrm{SnO}_{\mathrm{x}} @ \mathrm{AP}-\mathrm{H}_{2}$ & $1: 3.6: 2.8$ & 1: $4.1: 6.3$ & 1.7: 1 & 1: 0 & $0.2: 1$ \\
\hline $0.5 \% \mathrm{SnO}_{\mathrm{x}} @ \mathrm{AP}-\mathrm{ox}^{a}$ & $1: 3.7: 2.6$ & $0: 1: 8.6$ & undetectable & 1: 0.25 & $0: 1$ \\
\hline
\end{tabular}

The bulk atomic ratio of $\mathrm{Au} / \mathrm{Pd} / \mathrm{Sn}$ based on ICP and surface chemical composition based on XPS of different catalysts are summarized in Table 2. The atomic ratio of $\mathrm{Au} / \mathrm{Pd} / \mathrm{Sn}$ in the bulk of the $0.5 \% \mathrm{SnO}_{\mathrm{x}} @ \mathrm{AP}$-ox catalyst is 1: 3.6: 2.8, while the surface composition was found to be 1: $6.0: 23.8$ on the same catalyst. This result confirmed that most of $\mathrm{Sn}$ is distributed on the catalysts surface, which is consistent with EDX analysis (see line-scans and mapping in Figure 4). After the reduction, the $\mathrm{Au} / \mathrm{Pd} / \mathrm{Sn}$ ratio on the surface was dramatically changed to $1: 4.1: 6.3$, indicating that Sn partially entered in the bulk of NPs. This observation is consistent with the STEM-HADDF results showing that the reduction led to the transformation of surface Sn to the bulk, which may result in the formation of Au-Pd-Sn alloy NPs, 
and/or a reduced $\mathrm{SnO}_{\mathrm{x}}$ shell with different spreading on the Au-Pd particles. Furthermore, the strong interaction between $\mathrm{Pd}$ and $\mathrm{Sn}$ weakened the interaction between $\mathrm{Au}$ and $\mathrm{Pd}$, thus leading to the electron redistribution between $\mathrm{Au}-\mathrm{Pd}-\mathrm{Sn}$ atoms.

$\mathrm{H}_{2}$-TPR profiles of the catalysts are depicted in Figure 6A. The spectrum of monometallic catalyst Pd-ox contains a peak at $106{ }^{\circ} \mathrm{C}$ which is commonly attributed to the reduction of surface $\mathrm{PdO}$ species and a peak at $267^{\circ} \mathrm{C}$ ascribed to the reduction of bulk PdO. While in the spectrum of bimetallic catalyst AP-ox, the bulk reduction peak at $267^{\circ} \mathrm{C}$ disappeared, indicating alloying of $\mathrm{Au}$ and $\mathrm{Pd}$ that prevented the formation of bulk PdO phase. ${ }^{8-10}$ A negative reduction peak at $59{ }^{\circ} \mathrm{C}$ was observed for catalysts $0.2 \% \mathrm{SnO}_{\mathrm{x}} @ \mathrm{AP}-\mathrm{ox}, 0.5 \% \mathrm{SnO}_{\mathrm{x}} @ \mathrm{AP}-\mathrm{ox}$ and $1.0 \% \mathrm{SnO}_{\mathrm{x}} @ \mathrm{AP}-\mathrm{ox}$, which could be attributed to the decomposition of $\beta-\mathrm{PdH}_{\mathrm{x}}$. Since $\mathrm{PdO}$ species are easily reduced in a hydrogen atmosphere to metallic $\mathrm{Pd}$, which further interacts with hydrogen to form $\beta-\mathrm{PdH}_{\mathrm{x}}$ species. ${ }^{50-51}$ The presence of this peak indicated that $\mathrm{PdO}$ species on $\mathrm{SnO}_{\mathrm{x}}$ promoted catalysts are easily reduced to active $\mathrm{Pd}^{0}$ species or the $\mathrm{Pd}^{0}$ species are present. A reduction peak around $525^{\circ} \mathrm{C}$ is observed for sample $\mathrm{SnO}_{\mathrm{x}} @ \mathrm{MCF}-\mathrm{ox}$, which is due to the reduction of surface $\mathrm{SnO}_{\mathrm{x}}$ species, however, this peak shifts to $370{ }^{\circ} \mathrm{C}$ for catalysts $0.5 \% \mathrm{SnO}_{\mathrm{x}} @ \mathrm{AP}-\mathrm{ox}$ and $1.0 \% \mathrm{SnO}_{\mathrm{x}} @ \mathrm{AP}-\mathrm{ox}$, revealing that the interaction between $\mathrm{SnO}_{\mathrm{x}}$ and $\mathrm{Au}-\mathrm{Pd}$ NPs promotes the reduction of surface $\mathrm{SnO}_{x}$ species. Combined the $\mathrm{H}_{2}$-TPR with XPS results, one can conclude that the strong interaction between $\mathrm{SnO}_{\mathrm{x}}$ and $\mathrm{Au}-\mathrm{Pd} \mathrm{NPs}$ helps the reduction of surface 
$\mathrm{SnO}_{\mathrm{x}}$ and $\mathrm{PdO}$ species, which may act as oxygen transfer intermediate during the oxidation reaction.
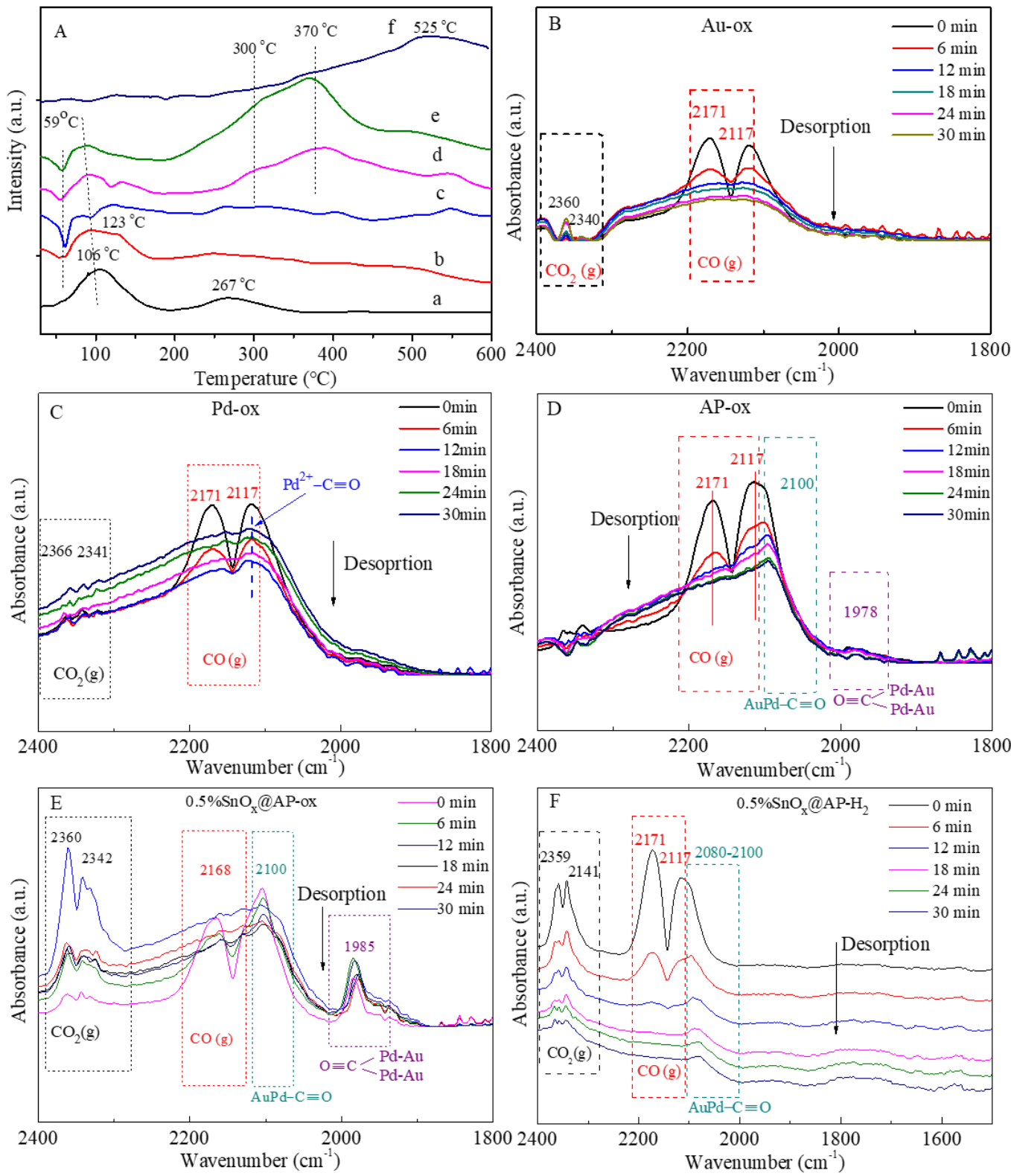

Figure 6. $\mathrm{H}_{2}$-TPR spectra (A) of catalysts (a) Pd-ox, (b) AP-ox, (c)
$0.2 \% \mathrm{SnO}_{\mathrm{x}} @ \mathrm{AP}-\mathrm{ox}$,
(d) $0.5 \% \mathrm{SnO}_{\mathrm{x}} @ \mathrm{AP}-\mathrm{ox}$,
(e) $1.0 \% \mathrm{SnO}_{\mathrm{x}} @ \mathrm{AP}-\mathrm{ox}$ and

(f)

$\mathrm{SnO}_{\mathrm{x}} @ \mathrm{MCF}-\mathrm{ox}$. Time-resolved CO-desorption DRIFTS spectra of catalysts (B) $\mathrm{Au}$ 
-ox, (C) Pd -ox, (D) AP-ox, (E) 0.5\% $\mathrm{SnO}_{\mathrm{x}} @ \mathrm{AP}-\mathrm{ox}$ and (F) $0.5 \% \mathrm{SnO}_{\mathrm{x}} @ \mathrm{AP}-\mathrm{H}_{2}$ at $25^{\circ} \mathrm{C}$.

The time-resolved CO adsorption DRIFTS spectra were conducted for all catalysts and presented in Figure 6B-F and Figure S4-5 (full spectral range). The bands at 2171 $\mathrm{cm}^{-1}$ and $\sim 2117 \mathrm{~cm}^{-1}$ are observed in the spectra for all samples and their intensity decreased with the $\mathrm{CO}$ desorption, which are ascribed to the physically adsorbed gaseous CO. ${ }^{52}$ The typical $\mathrm{CO}$ adsorption on $\mathrm{Au}$ at $2100 \sim 2000 \mathrm{~cm}^{-1}$ was not obvious $^{53}$ on catalyst $\mathrm{Au}$-ox (Figure 6B), which is probably due to the strong interaction between Au NPs and silica support. ${ }^{8}$ For catalyst Pd-ox (Figure 6C), the carbonyls on $\mathrm{Pd}^{2+}$ at $2117 \mathrm{~cm}^{-1}$ overlapping with adsorption bands of gaseous $\mathrm{CO}$ are confirmed, ${ }^{54}$ and this band does not disappear during $\mathrm{CO}$ desorption. A new band at $\sim 2100 \mathrm{~cm}^{-1}$ was observed on the bimetallic catalyst AP-ox (Figure 6D). The intensity of the latest band was enhanced for catalyst 0.5\% $\mathrm{SnO}_{\mathrm{x}} @ \mathrm{AP}-\mathrm{ox}$ (Figure 6E), associated with the linearly adsorbed $\mathrm{CO}$ on $\mathrm{Pd}^{\delta+}$ located in the corner or edge sites of Pd nanoparticles ${ }^{55-56}$. A weak adsorption band centered at $1985 \mathrm{~cm}^{-1}$ is present in the spectrum of catalysts AP-ox (Figure 6D) due to bridged CO adsorption on contiguous $\mathrm{Pd}^{0}$ sites or $\mathrm{Pd}^{0}$-enriched clusters $\left(v_{\mathrm{CO}}: 1900-2000 \mathrm{~cm}^{-1}\right)^{57}$ that was further enhanced for catalyst $0.5 \% \mathrm{SnO}_{\mathrm{x}} @ \mathrm{AP}-\mathrm{ox}$ (Figure 6E), indicating the formation of $\mathrm{Pd}^{0}$-enriched clusters after introducing $\mathrm{SnO}_{\mathrm{x}}$. Whereas, the enhanced intensity of the band at $\sim 2100 \mathrm{~cm}^{-1}$ reflecting the increase of linearly adsorbed CO on $\mathrm{Pd}^{0}$ sites. These results reveal the increase of both $\mathrm{Pd}^{0}$-enriched clusters and single $\mathrm{Pd}^{0}$ sites on catalyst $0.5 \% \mathrm{SnO}_{\mathrm{x}} @ \mathrm{AP}-\mathrm{ox}$, which is consistent with $\mathrm{XRD}$ and XPS results. After $\mathrm{H}_{2}$ 
reduction (Figure $6 \mathrm{~F}$ ), the band corresponding to the bridged adsorption of $\mathrm{CO}$ on $\mathrm{Pd}^{0}$ at $1985 \mathrm{~cm}^{-1}$ disappeared, indicating the reconstruction of $\mathrm{Pd}^{0}$-enriched clusters to Au-Pd-Sn or Pd-Sn alloy NPs. The $\mathrm{CO}_{2}$ vibration peaks $\left(\sim 2360 \text { and } \sim 2340 \mathrm{~cm}^{-1}\right)^{52}$ were detected on $\mathrm{SnO}_{\mathrm{x}}$ promoted catalysts $0.5 \% \mathrm{SnO}_{\mathrm{x}} @ \mathrm{AP}-\mathrm{ox}$ and $0.5 \% \mathrm{SnO}_{\mathrm{x}} @ \mathrm{AP}-\mathrm{H}_{2}$, revealing that $\mathrm{CO}$ was readily oxidized to $\mathrm{CO}_{2}$ on these catalysts at room temperature $\left(25^{\circ} \mathrm{C}\right)$. Especially on unreduced catalyst $0.5 \% \mathrm{SnO}_{\mathrm{x}} @ \mathrm{AP}-\mathrm{ox}$, the intensity of $\mathrm{CO}_{2}$ adsorption bands increased as the desorption proceeds (Figure 6E, black frame), indicating that the adsorbed gaseous $\mathrm{CO}$ was oxidized to $\mathrm{CO}_{2}$. These results indicated that $\mathrm{SnO}_{\mathrm{x}}$ could serve as an oxygen transfer medium which would enhance the oxygen transfer during partial oxidation of benzyl alcohol over Au-Pd NPs catalyst.

3.2 Catalytic Evaluation. The activity for benzyl alcohol oxidation and benzaldehyde selectivity of different catalysts are presented in Figure 7A; detailed oxidation results are summarized in Table S1. The external and internal diffusion limitations have been neglected based on the results from our recent study. ${ }^{58}$ Therefore, the TOFs is used to represent the intrinsic activity of catalysts in the current study. As is shown (Figure 7A and Table S1), the catalytic activity on unreduced monometallic catalysts $(\mathrm{Au}, \mathrm{Pd}, \mathrm{Sn})$ and bimetallic catalysts ( $\mathrm{Au}-\mathrm{Pd}$, Au-Sn, Pd-Sn) are low. But a significant enhancement of catalytic activity was achieved on $\mathrm{SnO}_{\mathrm{x}}$ promoted catalyst $0.5 \% \mathrm{SnO}_{\mathrm{x}} @ \mathrm{AP}-\mathrm{ox}$, indicating a synergy among different $\mathrm{Au}, \mathrm{SnO}_{\mathrm{x}}$ and $\mathrm{Pd}$ species. Catalyst AP-ox exhibited a low catalytic activity $\left(\mathrm{TOF}=4365 \mathrm{~h}^{-1}\right)$ for benzyl alcohol oxidation because inert PdO species exist as the 
dominant surface species (see XPS spectra, Figure 4B). After introducing 0.5wt.\% $\mathrm{SnO}_{\mathrm{x}}$, a higher catalytic activity $\left(\mathrm{TOF}=13662 \mathrm{~h}^{-1}\right)$ was achieved on catalyst $0.5 \% \mathrm{SnO}_{\mathrm{x}} @ \mathrm{AP}-\mathrm{ox}$, due to the presence of active $\mathrm{Pd}^{0}$ species on the catalyst surface. Thus, the introduction of $\mathrm{SnO}_{\mathrm{x}}$ promoted the partial reduction of $\mathrm{PdO}$ to $\mathrm{Pd}^{0}$ and formation of more $\mathrm{Pd}^{0}$-enriched clusters on catalyst $0.5 \% \mathrm{SnO}_{\mathrm{x}} @ \mathrm{AP}$-ox, leading to catalytic activity enhancement. However, the catalytic activity decreases on the $\mathrm{H}_{2}$ reduced catalyst $0.5 \% \mathrm{SnO}_{\mathrm{x}} @ \mathrm{AP}-\mathrm{H}_{2}$, where most of $\mathrm{PdO}$ species are believed to be reduced to $\mathrm{Pd}^{0}$. The low catalytic activity of catalyst $0.5 \% \mathrm{SnO}_{\mathrm{x}} @ \mathrm{AP}-\mathrm{H}_{2}$ is due to the formation of Au-Pd-Sn alloy NPs with uniform composition, which results in the decrease of active $\mathrm{Pd}^{0}$-enriched clusters as shown by $\mathrm{CO}$ adsorption FT-IR ${ }^{13}$ It is also noted that no obvious enhancement of catalytic activity was observed on $\mathrm{SnO}_{\mathrm{x}}$ promoted Pd NP catalysts no matter whether were or not treated under $\mathrm{H}_{2}$ (catalysts 0.5\% $\mathrm{SnO}_{\mathrm{x}} @ \mathrm{Pd}-\mathrm{ox}$ and 0.5\% $\mathrm{SnO}_{\mathrm{x}} @ \mathrm{Pd}-\mathrm{H}_{2}, \mathrm{TOF}=7500-7800 \mathrm{~h}^{-1}$ ), Table S1. These results indicate that the effect of $\mathrm{Au}$ on the catalyst performance should not be ignored. The role of $\mathrm{Au}$ on the Au-Pd alloy NP catalyst was usually considered as a structural and electronic promoter, which fostered the formation of active $\mathrm{Pd}^{0}$-enriched sites. It is worth noting that a significant enhancement of benzaldehyde selectivity (from $60.1 \%$ on catalyst AP-ox to $73.2 \%$ on catalyst $0.5 \% \mathrm{SnO}_{\mathrm{x}} @ \mathrm{AP}$-ox) was achieved after introducing the $\mathrm{SnO}_{\mathrm{x}}$ promoter, and especially the benzaldehyde yield increased from $15.7 \%$ (AP-ox) to $59.8 \%\left(0.5 \% \mathrm{SnO}_{\mathrm{x}} @ \mathrm{AP}-\mathrm{ox}\right)$ after $2 \mathrm{~h}$ reaction. The benzaldehyde selectivity increased with the increase of $\mathrm{SnO}_{\mathrm{x}}$ content, which should be related to the surface properties of the catalyst. Similar results were also 
reported by Hutchings and coworkers for $\mathrm{H}_{2} \mathrm{O}_{2}$ synthesis. ${ }^{13} \mathrm{SnO}_{\mathrm{x}}$ promoted $\mathrm{Pd} / \mathrm{TiO}_{2}$ catalyst exhibited high $\mathrm{H}_{2} \mathrm{O}_{2}$ selectivity attributable to the surface modification of $\mathrm{SnO}_{\mathrm{x}}$ to $\mathrm{Pd}$ sites.
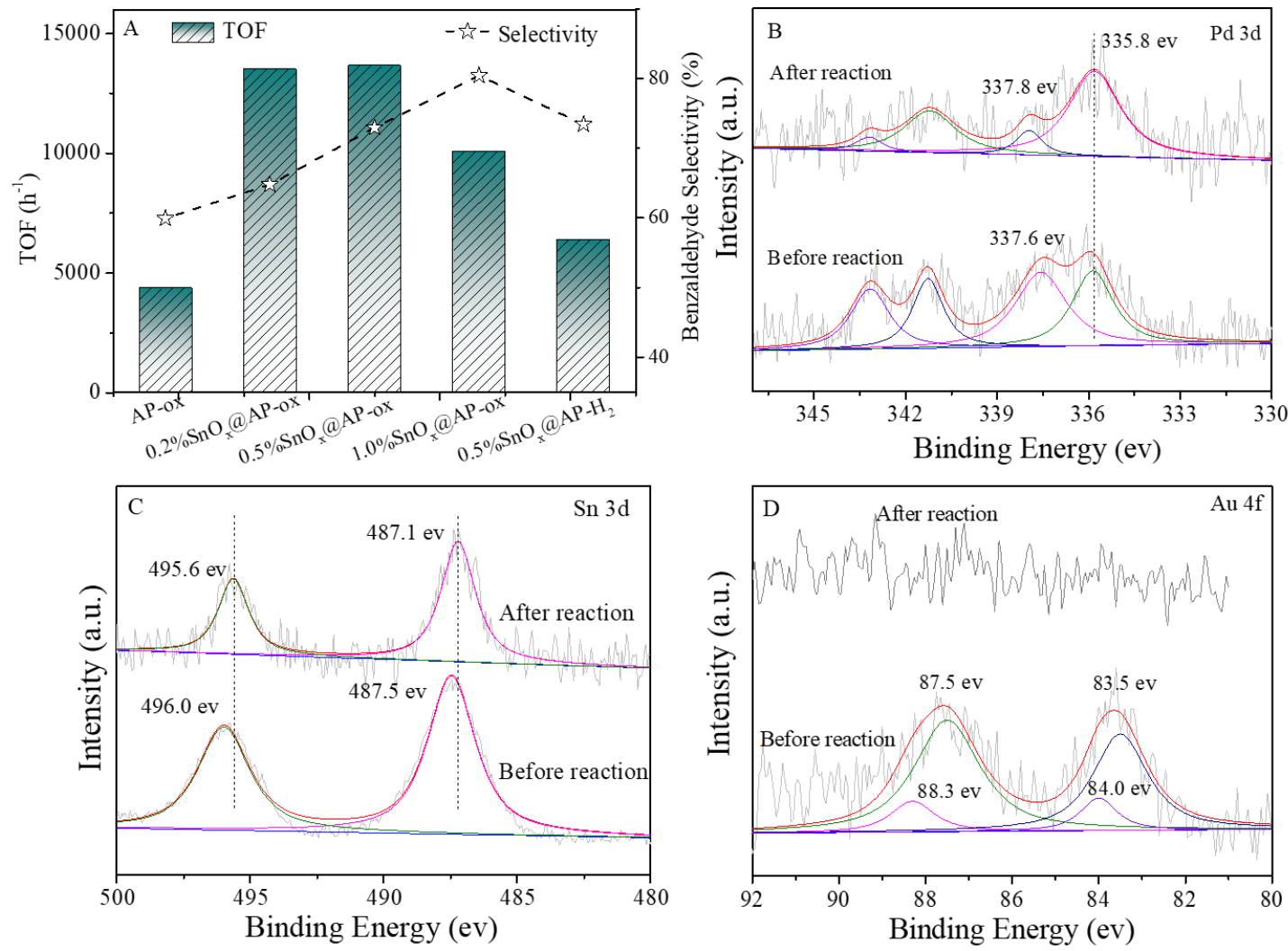

Figure 7. (A) Performance (TOF) of catalysts, XPS spectra of Pd 3d (B), Sn 3d (C), and $\mathrm{Au} 4 \mathrm{f}(\mathrm{D})$ before and after control reaction (reaction conditions: $50.0 \mathrm{mg}$ catalyst, $10.8 \mathrm{~g}$ benzyl alcohol, nitrogen pressure of $0.8 \mathrm{MPa}$, reaction temperature of $110^{\circ} \mathrm{C}$ reaction time of $2 \mathrm{~h}$, stirring rate of $800 \mathrm{r} / \mathrm{min}$ ).

In order to study the catalytic mechanism of benzyl alcohol oxidation on $\mathrm{SnO}_{\mathrm{x}}$ promoted Au-Pd catalyst, the control reaction was carried out on catalyst $0.5 \% \mathrm{SnO}_{\mathrm{x}} @ \mathrm{AP}-\mathrm{ox}$ under the same reaction conditions except for using $\mathrm{N}_{2}$ atmosphere. A benzyl alcohol conversion of $5.8 \%$ with benzaldehyde selectivity of 
$85.3 \%$ were obtained after $2 \mathrm{~h}$ reaction. The surface properties of the used catalyst were characterized by XPS, Figure 7B-D. A significant increase of $\mathrm{Pd}^{0} / \mathrm{Pd}^{2+}$ ratio from 1:1.2 to 1:0.25 was observed after the reaction under $\mathrm{N}_{2}$ atmosphere, indicating that $\mathrm{PdO}$ participates in the oxygen transfer during the oxidation reaction. The $\mathrm{BE}$ of Sn $3 \mathrm{~d}$ shifted from $487.5 \mathrm{eV}$ to $487.1 \mathrm{eV}$ revealing the partial reduction of $\mathrm{SnO}_{\mathrm{x}}$ to lower valance state $\mathrm{SnO}_{\mathrm{x}-\delta}$ (Figure 7C). However, no surface $\mathrm{Au}$ species are detected after the reaction. ICP results revealed no obvious leaching of Au during the control reaction (Table 2). These results indicated that both $\mathrm{PdO}$ and $\mathrm{SnO}_{2}$ were reduced in the control reaction, namely participating in the oxygen transfer during the oxidation, which is in good accordance with time resolved CO-DRIFTS data. The surface $\mathrm{Pd} / \mathrm{Sn}$ ratio decreased from 0.25 to 0.12 after the reaction, indicating the surface accumulation of $\mathrm{Sn}$ on $\mathrm{Au}-\mathrm{Pd}-\mathrm{Sn} \mathrm{NPs}$, while $\mathrm{Au}$ transferred to the inner bulk or covered by Sn-Pd.

Correlating the characterization results with the activity of the catalyst $\left(0.5 \% \mathrm{SnO}_{\mathrm{x}} @ \mathrm{AP}-\mathrm{ox}\right)$, we could conclude that the introduction of $\mathrm{SnO}_{\mathrm{x}}$ promotes the partial reduction of surface $\mathrm{PdO}$ to active $\mathrm{Pd}^{0}$ species. Both $\mathrm{PdO}$ and $\mathrm{SnO}_{\mathrm{x}}$ participated in the oxygen transfer reaction, leading to a high catalytic activity. After $\mathrm{H}_{2}$ reduction, the $\mathrm{PdO}$ was completely reduced to $\mathrm{Pd}^{0}$, while $\mathrm{SnO}_{\mathrm{x}}$ was partially reduced and migrated to the bulk of Au-Pd NPs to form Au-Pd-Sn alloy NPs. A low catalytic activity was observed on catalyst $0.5 \% \mathrm{SnO}_{\mathrm{x}} @ \mathrm{AP}-\mathrm{H}_{2}$, which is due to the formation of surface Au-Pd-Sn alloy. 
3.3 DFT Calculation. The DFT calculations were applied to further explain the reconstruction of active sites on $\mathrm{SnO}_{\mathrm{x}}$ promoted $\mathrm{Au}-\mathrm{Pd}$ catalysts and the results are shown in Table 3. It was found that the bond energy of Sn-O is $141.1 \mathrm{kcal} / \mathrm{mol}$, which is significantly higher than that of the $\mathrm{Pd}-\mathrm{O}$ bond $(86.8 \mathrm{kcal} / \mathrm{mol})$, therefore, part of $\mathrm{PdO}$ species would be reduced by $\mathrm{Sn}$ and more $\mathrm{Pd}^{0}$ sites were generated after introducing Sn (XPS results). Simultaneously, the formation energy of different alloys was calculated to verify the reconstruction of active sites after $\mathrm{H}_{2}$ reduction. The results indicated that the absolute value of $\mathrm{Pd}_{3} \mathrm{Au}$ formation energy $(-0.43 \mathrm{eV})$ is quite smaller than that of $\mathrm{Pd}_{3} \mathrm{Sn}(-1.84 \mathrm{eV})$, which explained the easy formation of $\mathrm{Pd}-\mathrm{Sn} / \mathrm{Au}-\mathrm{Pd}-\mathrm{Sn}$ alloy after $\mathrm{H}_{2}$ reduction and justified the experimental results.

Table 3. The bond energies of different $\mathrm{M}-\mathrm{O}$ bonds and formation energies of different alloys.

\begin{tabular}{|c|c|c|c|}
\hline $\mathrm{M}-\mathrm{O}$ & Bond energy $(\mathrm{kcal} / \mathrm{mol})$ & Alloys & $\mathrm{E}_{\mathrm{f}}(\mathrm{eV})$ \\
\hline $\mathrm{Sn}-\mathrm{O}$ & -141.2 & $\mathrm{Pd}_{3} \mathrm{Au}$ & -0.43 \\
\hline OSn-O & -76.3 & $\mathrm{Pd}_{3} \mathrm{Sn}$ & -1.84 \\
\hline $\mathrm{Pd}-\mathrm{O}$ & -86.8 & & \\
\hline
\end{tabular}


Adsorption energy of benzyl alcohol Desorption energy of benzaldehyde

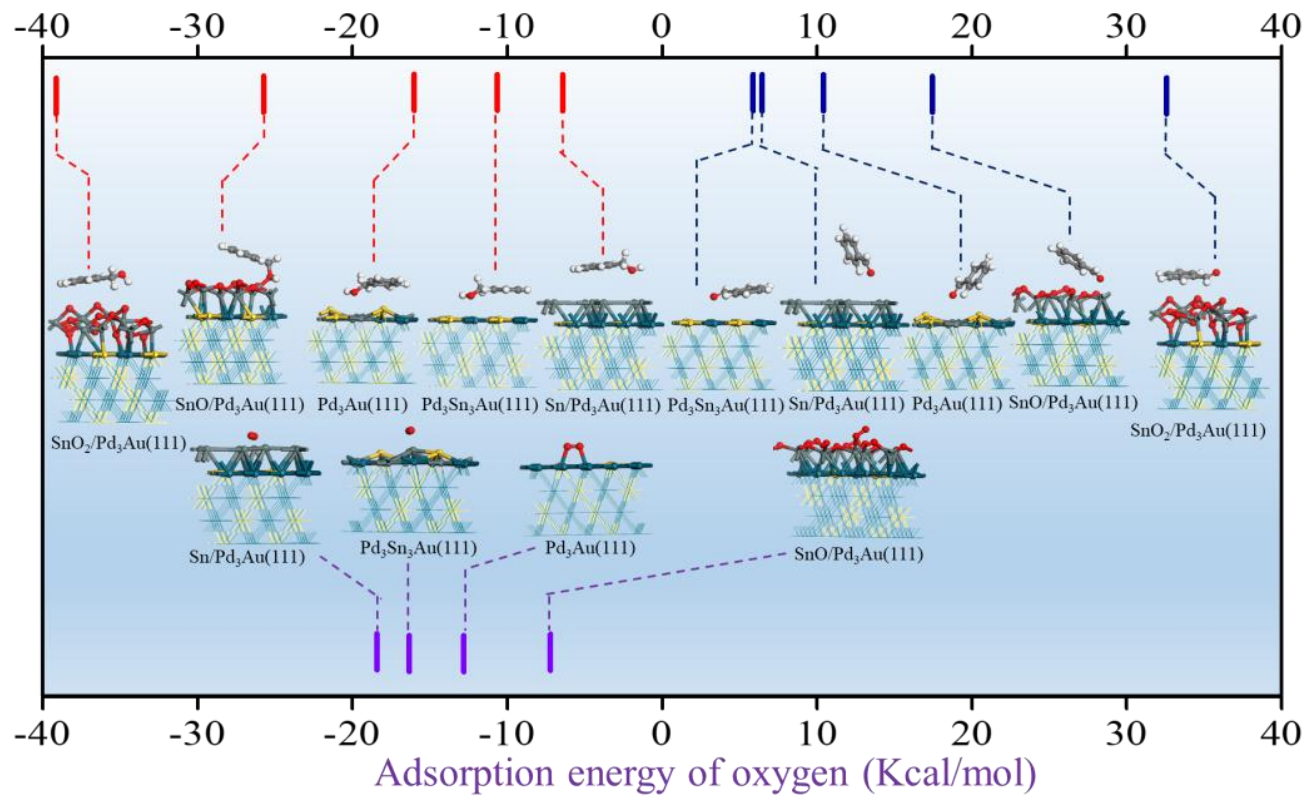

Figure 8. Adsorption/desorption energies and configurations of benzyl alcohol, $\mathrm{O}_{2}$ and benzaldehyde on $\mathrm{Pd}_{3} \mathrm{Au}(111), \quad \mathrm{SnO}_{\mathrm{x}} / \mathrm{Pd}_{3} \mathrm{Au}(111), \quad \mathrm{Sn}_{3} \mathrm{Pd}_{3} \mathrm{Au}(111)$ and $\mathrm{Sn} / \mathrm{Pd}_{3} \mathrm{Au}(111)$ surfaces (blue, yellow, gray in the catalyst, gray in the benzene ring, red, and white balls denote $\mathrm{Pd}, \mathrm{Au}, \mathrm{Sn}, \mathrm{C}, \mathrm{O}$, and $\mathrm{H}$ atoms, respectively). Note: The adsorption energy and desorption energy are calculated by the same equation but with opposite values. The term of adsorption energy was applied for reactants (benzyl alcohol and oxygen), while the term of desorption energy was applied for product for distinction.

The catalytic activity and useful product selectivity of benzyl alcohol partial oxidation were closely related to the adsorption properties and surface O species. ${ }^{59-60}$ Thus, the adsorption/desorption energies and configurations of benzyl alcohol, $\mathrm{O}_{2}$ and benzaldehyde on $\mathrm{Pd}_{3} \mathrm{Au}(111), \mathrm{Sn}_{3} \mathrm{Pd}_{3} \mathrm{Au}(111), \mathrm{Sn} / \mathrm{Pd}_{3} \mathrm{Au}(111), \mathrm{SnO} / \mathrm{Pd}_{3} \mathrm{Au}(111)$, and $\mathrm{SnO}_{2} / \mathrm{Pd}_{3} \mathrm{Au}(111)$, whereas the detailed energy barrier for the $\mathrm{O}_{2}$ decomposition into 2 
$\mathrm{O}$, the adsorption energy of benzyl alcohol and oxygen, and the desorption energy of the products are presented in Figure 8 and listed in Table S2. Compared with the bimetallic $\mathrm{Pd}_{3} \mathrm{Au}(111)$ surface, the $\mathrm{Sn}$ containing surfaces $\left(\mathrm{Sn} / \mathrm{Pd}_{3} \mathrm{Au}\right.$ (111) and $\left.\mathrm{SnO} / \mathrm{Pd}_{3} \mathrm{Au}(111)\right)$ are conducive for the adsorption and activation of oxygen molecules, since the decomposition energy barrier of the $\mathrm{O}_{2}$ decomposition is significantly reduced from $42.5 \mathrm{kcal} / \mathrm{mol}$ on the $\mathrm{Pd}_{3} \mathrm{Au}(111)$ surface to $19.2 \mathrm{kcal} / \mathrm{mol}$ on the $\mathrm{Sn} / \mathrm{Pd}_{3} \mathrm{Au}(111)$ surface and to $33.5 \mathrm{kcal} / \mathrm{mol}$ on the $\mathrm{SnO} / \mathrm{Pd}_{3} \mathrm{Au}(111)$ surface. The adsorption energies of benzyl alcohol on the $\mathrm{SnO} / \mathrm{Pd}_{3} \mathrm{Au}(111)$ and $\mathrm{SnO}_{2} / \mathrm{Pd}_{3} \mathrm{Au}(111)$ surfaces are $32.0 \mathrm{kcal} / \mathrm{mol}$ and $39.2 \mathrm{kcal} / \mathrm{mol}$, respectively, much higher than those of other surfaces, indicating that benzyl alcohol could be easily adsorbed on the $\mathrm{SnO} / \mathrm{Pd}_{3} \mathrm{Au}(111)$ and $\mathrm{SnO}_{2} / \mathrm{Pd}_{3} \mathrm{Au}(111)$ interfaces. On the other hand, the adsorption energy of benzaldehyde on the reduced surfaces $\left(\mathrm{SnO} / \mathrm{Pd}_{3} \mathrm{Au}(111)\right.$ and $\left.\mathrm{Sn} / \mathrm{Pd}_{3} \mathrm{Au}(111)\right)$ is lower than that on the surface of $\mathrm{SnO}_{2} / \mathrm{Pd}_{3} \mathrm{Au}(111)$, which indicates benzaldehyde easily desorbed from the $\mathrm{SnO} / \mathrm{Pd}_{3} \mathrm{Au}(111)$ or $\mathrm{Sn} / \mathrm{Pd}_{3} \mathrm{Au}(111)$ interface. The characterization results revealed that $\mathrm{SnO}_{2}$ participates in the oxygen transfer reaction and is partially reduced during the reaction (Figure 7C). Benzyl alcohol was easily adsorbed on the $\mathrm{SnO}_{2} / \mathrm{Pd}_{3} \mathrm{Au}$ (111) surface and oxidized by $\mathrm{SnO}_{2}$, and at the same time, the $\mathrm{SnO}_{2} / \mathrm{Pd}_{3} \mathrm{Au}$ (111) interface was reduced to $\mathrm{SnO} / \mathrm{Pd}_{3} \mathrm{Au}(111)$ or $\mathrm{Sn} / \mathrm{Pd}_{3} \mathrm{Au}(111)$ which are beneficial for the benzaldehyde desorption. The reduced interfaces $\mathrm{SnO} / \mathrm{Pd}_{3} \mathrm{Au}$ (111) and $\mathrm{Sn} / \mathrm{Pd}_{3} \mathrm{Au}(111)$ continue to adsorb oxygen and participate in the next reaction cycle (Figure 9A). However, when the catalyst was completely reduced $\left(\mathrm{Pd}_{3} \mathrm{Sn}_{3} \mathrm{Au}\right.$ alloy formation), the adsorption energies of benzyl 
alcohol decreased (from $16.2 \mathrm{kcal} / \mathrm{mol}$ on $\mathrm{AuPd}_{3}$ alloy to $10.5 \mathrm{kcal} / \mathrm{mol}$ on $\mathrm{Pd}_{3} \mathrm{Sn}_{3} \mathrm{Au}$ alloy), the adsorption distance increased $(2.502 \AA \rightarrow 2.698 \AA)$, thus, leading to a low catalytic activity on $\mathrm{H}_{2}$-reduced catalyst $0.5 \% \mathrm{SnO}_{\mathrm{x}} @ \mathrm{AP}-\mathrm{H}_{2}$.

Based on the above results, a reaction mechanism was proposed (Figure 9B). The enhanced catalytic activity on $\mathrm{SnO}_{\mathrm{x}}$ promoted AP catalyst was due to the presence of high oxophilic Sn, which promoted the partial reduction of $\mathrm{PdO}$ to active $\mathrm{Pd}^{0}$. Both $\mathrm{PdO}$ and $\mathrm{SnO}_{\mathrm{x}}$ participated in the partial oxidation reaction and enhanced the $\mathrm{O}$ transfer, thus leading to a high catalytic activity. The redox switching of $\mathrm{SnO}_{\mathrm{x}}$ with $\mathrm{SnO}_{\mathrm{x}-\delta}$ changed the catalyst surface affinity to benzyl alcohol and benzaldehyde. Benzyl alcohol was easily adsorbed on $\mathrm{SnO}_{2} / \mathrm{Pd}_{3} \mathrm{Au}(111)$ surface, and $\mathrm{SnO}_{2}$ participated in the oxygen transfer via reduction to $\mathrm{SnO} / \mathrm{Pd}_{3} \mathrm{Au}(111)$ or $\mathrm{Sn} / \mathrm{Pd}_{3} \mathrm{Au}(111)$, which is crucial for the benzaldehyde desorption, leading to a high benzaldehyde selectivity. The $\mathrm{SnO} / \mathrm{Pd}_{3} \mathrm{Au}$ or $\mathrm{Sn} / \mathrm{Pd}_{3} \mathrm{Au}$ reduced surfaces readily adsorb and react with oxygen to form $\mathrm{SnO}_{2} / \mathrm{Pd}_{3} \mathrm{Au}$ and participate in the next reaction cycle.
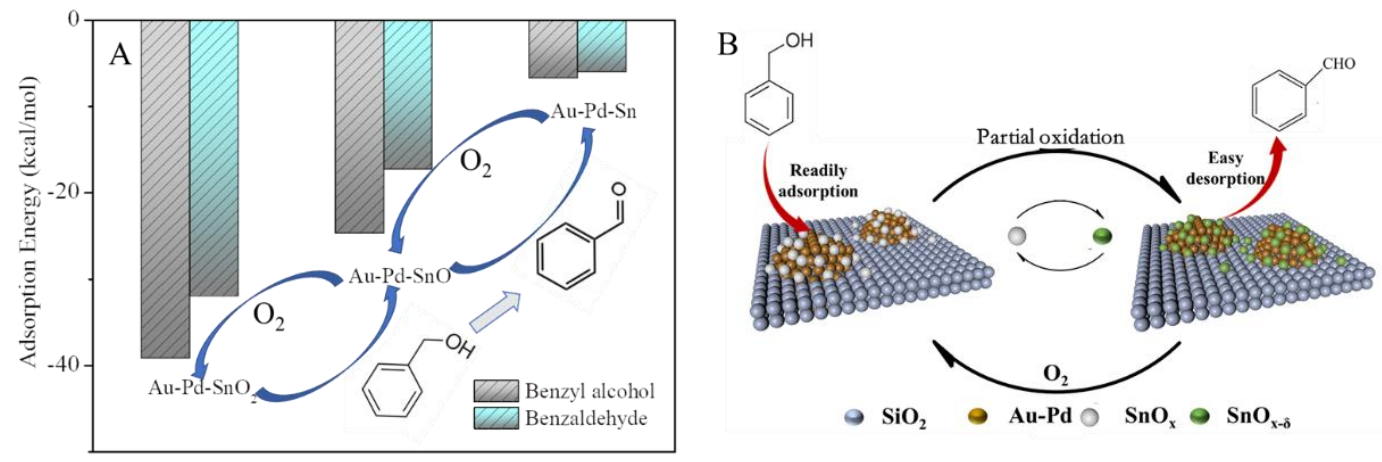

Figure 9. (A) Adsorption energy of benzyl alcohol and benzaldehyde on $\mathrm{SnO}_{2} / \mathrm{Pd}_{3} \mathrm{Au}(111), \mathrm{SnO} / \mathrm{Pd}_{3} \mathrm{Au}(111)$ and $\mathrm{Sn} / \mathrm{Pd}_{3} \mathrm{Au}(111)$ surfaces, and (B) Schematic 
illustration of benzyl alcohol and benzaldehyde adsorption/desorption on $\mathrm{SnO}_{\mathrm{x}} / \mathrm{Au}-\mathrm{Pd}$ and $\mathrm{SnO}_{\mathrm{x}-\delta} / \mathrm{Au}-\mathrm{Pd}$ surface.

\section{CONCLUSIONS}

In this study, $\mathrm{SnO}_{\mathrm{x}}$ was introduced into the $\mathrm{Au}-\mathrm{Pd}$ bimetal catalyst as a promoter. Based on the comprehensive experimental and theoretical results we found out that the introduction of $\mathrm{SnO}_{\mathrm{x}}$ promotes the partial reduction of $\mathrm{PdO}$ to active $\mathrm{Pd}^{0}$-enriched clusters on unreduced catalyst, which is due to the high oxophilicity of Sn. The presence of more active $\mathrm{Pd}^{0}$-enriched clusters, together with the enhancement of $\mathrm{O}$ transfer by $\mathrm{PdO}$ and $\mathrm{SnO}_{\mathrm{x}}$, results in the highest catalytic activity $\left(13662 \mathrm{~h}^{-1}\right)$ for benzyl alcohol oxidation on catalyst $0.5 \% \mathrm{SnO}_{\mathrm{x}} @ \mathrm{AP}-\mathrm{ox}$, while the benzaldehyde selectivity increased with $\mathrm{SnO}_{\mathrm{x}}$ ratio. The enhanced benzaldehyde selectivity on $\mathrm{SnO}_{\mathrm{x}}$ promoted catalysts $y \mathrm{SnO}_{\mathrm{x}} @ \mathrm{AP}-\mathrm{ox}$ was due to the in-situ regulation of reactants and products affinity on the catalyst surface through redox switching of $\mathrm{SnO}_{\mathrm{x}}$ with $\mathrm{SnO}_{\mathrm{x}-\delta}$ during oxidation reaction. After $\mathrm{H}_{2}$ reduction, the $\mathrm{SnO}_{\mathrm{x}}$ was partially reduced and Au-Pd-Sn alloy was formed leading to a reduced activity of the catalyst. The theoretical results revealed that the formation of $\mathrm{Pd}-\mathrm{Sn} / \mathrm{Au}-\mathrm{Pd}-\mathrm{Sn}$ alloy weakens the adsorption of benzyl alcohol on catalysts $\mathrm{SnO}_{\mathrm{x}} @ \mathrm{AP}-\mathrm{H}_{2}$. In summary, the $\mathrm{SnO}_{\mathrm{x}}$

promoted autogenous reduction of $\mathrm{PdO}$ to active $\mathrm{Pd}^{0}$ species together with the enhancement of $\mathrm{O}$ transfer by $\mathrm{PdO}$ and $\mathrm{SnO}_{\mathrm{x}}$ leading to high catalytic activity, while the $\mathrm{SnO}_{\mathrm{x}}$ redox switching during the oxidation reaction modulated the adsorption properties of reactants and products which enhanced the benzaldehyde selectivity. 


\section{ASSOCIATED CONTENT}

Supporting Information: $\mathrm{N}_{2}$ adsorption/desorption isotherms; XRD spectra; Solid UV-vis spectra of reduced catalysts; DRIFT spectra using CO probe molecule adsorbed on different catalysts, the time-resolved DRIFTS spectra collected on different catalysts at $25{ }^{\circ} \mathrm{C}$ under $1 \% \mathrm{CO}$ in $\mathrm{He}$ (in the full range); Catalyst benzyl alcohol oxidation results; Adsorption of benzyl alcohol, desorption of benzaldehyde, reaction energy barrier of $\mathrm{O}_{2}$ and adsorption energy of oxygen on the catalyst surface.

\section{AUTHOR INFORMATION}

\section{Corresponding Authors}

Peng Bai- State Key Laboratory of Heavy Oil Processing, Key Laboratory of Catalysis, College of Chemical Engineering, China University of Petroleum (East China), Qingdao 266580, China;

\section{Email:baipeng@upc.edu.cn}

Lianming Zhao- School of Materials Science and Engineering, Institute of Advanced Materials, China University of Petroleum (East China), Qingdao, 266580, China;

Email:Llmzhao@upc.edu.cn

\section{Authors}

Pingping Wu- State Key Laboratory of Heavy Oil Processing, Key Laboratory of Catalysis, College of Chemical Engineering, China University of Petroleum (East China), Qingdao 266580, China; 
Zhengke He- State Key Laboratory of Heavy Oil Processing, Key Laboratory of Catalysis, College of Chemical Engineering, China University of Petroleum (East China), Qingdao 266580, China;

Yonghui Liu- School of Materials Science and Engineering, Institute of Advanced Materials, China University of Petroleum (East China), Qingdao, 266580, China;

Lei Song- State Key Laboratory of Heavy Oil Processing, Key Laboratory of Catalysis, College of Chemical Engineering, China University of Petroleum (East China), Qingdao 266580, China;

Edgar Muhumuza- State Key Laboratory of Heavy Oil Processing, Key Laboratory of Catalysis, College of Chemical Engineering, China University of Petroleum (East China), Qingdao 266580, China;

Svetlana Mintova- Normandie University, ENSICAEN, UNICAEN, CNRS, Laboratoire Catalyse et Spectrochimie, 14000 Caen, France

Zifeng Yan- State Key Laboratory of Heavy Oil Processing, Key Laboratory of Catalysis, College of Chemical Engineering, China University of Petroleum (East China), Qingdao 266580, China;

\section{Notes}

The authors declare no competing financial interest.

\section{- ACKNOWLEDGEMENTS}


This work was financially supported by the Natural Science Foundation of China (51601223, 21908246, 21991090), the Fundamental Research Funds for the Central Universities (17CX05018, 17CX02056), Shandong Provincial Natural Science Foundation (ZR201702160196), State Key Laboratory of Heavy Oil Processing SKLZZ-2017008) and the Sino-French International Laboratory (LIA) “Zeolites”.

\section{REFERENCES}

(1). He, Q.; Miedziak, P. J.; Kesavan, L.; Dimitratos, N.; Sankar, M.; Lopez-Sanchez, J. A.; Forde, M. M.; Edwards, J. K.; Knight, D. W.; Taylor, S. H. Switching-off Toluene Formation in the Solvent-free Oxidation of Benzyl Alcohol using Supported Trimetallic Au-Pd-Pt Nanoparticles. Faraday Discuss. 2013, 162 (8), 365-378.

(2). Al-Saeedi, S.; Abdel-Rahman, L.; Abu-Dief, A.; Abdel-Fatah, S.; Alotaibi, T.; Alsalme, A.; Nafady, A. Catalytic Oxidation of Benzyl Alcohol Using Nanosized $\mathrm{Cu} / \mathrm{Ni}$ Schiff-Base Complexes and Their Metal Oxide Nanoparticles. Catalysts 2018, $8(10), 452$

(3). Campisi, S.; Ferri, M.; Chan-Thaw, C. E.; Sanchez Trujillo, F. J.; Motta, D.; Tabanelli, T.; Dimitratos, N.; Villa, A. Metal-Support Cooperative Effects in Au/VPO for the Aerobic Oxidation of Benzyl Alcohol to Benzyl Benzoate. Nanomaterials 2019, 9 (2), 299.

(4). Xiao, C.; Zhang, L.; Hao, H.; Wang, W. High Selective Oxidation of Benzyl Alcohol to Benzylaldehyde and Benzoic Acid with Surface Oxygen Vacancies on $\mathrm{W}_{18} \mathrm{O}_{49} /$ Holey Ultrathin $\mathrm{g}-\mathrm{C}_{3} \mathrm{~N}_{4}$ Nanosheets. ACS Sustainable Chem. Eng. 2019, 7 (7), 
7268-7276.

(5). Ding, J.; Xu, W.; Wan, H.; Yuan, D.; Chen, C.; Wang, L.; Guan, G.; Dai,

W.-L. Nitrogen Vacancy Engineered Graphitic $\mathrm{C}_{3} \mathrm{~N}_{4}$-based Polymers for Photocatalytic Oxidation of Aromatic Alcohols to Aldehydes. Appl. Catal. B-Environ. 2018, 221, 626-634.

(6). Olmos, C. M.; Chinchilla, L. E.; Cappella, A. M.; Villa, A.; Delgado, J. J.; Hungría, A. B.; Blanco, G.; Calvino, J. J.; Prati, L.; Chen, X. Selective Oxidation of Veratryl Alcohol over $\mathrm{Au}-\mathrm{Pd} / \mathrm{Ce}_{0.62} \mathrm{Zr}_{0.38} \mathrm{O}_{2}$ Catalysts Synthesized by Sol-Immobilization: Effect of Au: Pd Molar Ratio. Nanomaterials 2018, 8 (9), 669.

(7). Xin, J.-y.; Fan, H.C.; Ji, S.F.; Wang, Y.; Xia, C.G. Methanobactin-mediated Synthesis of Bimetallic Au-Pd/Al $\mathrm{O}_{2} \mathrm{O}_{3}$ Toward an Efficient Catalyst for Glucose Oxidation. Iet Nanobiotechnol. 2017, 11 (5), 512-516.

(8). Wu, P.; Cao, Y.; Zhao, L.; Wang, Y.; He, Z.; Xing, W.; Bai, P.; Mintova, S.; Yan, Z. Formation of PdO on Au-Pd Bimetallic Catalysts and the Effect on Benzyl Alcohol Oxidation. J. Catal. 2019, 375, 32-43.

(9). $\quad \mathrm{Xu}$, J. W., T.; Li, P.; He, C.; Yu, J.; Yuan, W.; Han, Y.F. . Biphasic Pd-Au Alloy Catalyst for Low-Temperature CO Oxidation. J. Am. Chem. Soc. 2010, 132, 10398-10406.

(10). Li, Z. G., F.; Furlong, O.; Tysoe, W. T. Adsorption of Carbon Monoxide $\mathrm{Au} / \mathrm{Pd}$ (100) Alloys in Ultrahigh Vacuum: Identification of Adsorption Sites. Surf. Sci. 2010, 604, 136-143.

(11). Ghazal Tofighi, X. Y., Henning Lichtenberg, Dmitry E. Doronkin, Wu Wang, 
Christof Wöll, Yuemin Wang, and Jan-Dierk Grunwaldt. Chemical Nature of Microfluidically Synthesized AuPd Nanoalloys Supported on $\mathrm{TiO}_{2}$. ACS Catal. 2019, $9(6), 5462-5473$.

(12). Han, S.; Mullins, C. B. Surface Alloy Composition Controlled $\mathrm{O}_{2}$ Activation on Pd-Au Bimetallic Model Catalysts. ACS Catal. 2018, 8 (4), 3641-3649.

(13). Freakley, S. J.; He, Q.; Harrhy, J. H.; Lu, L.; Crole, D. A.; Morgan, D. J.; Ntainjua, E. N.; Edwards, J. K.; Carley, A. F.; Borisevich, A. Y.; Kiely, C. J.; Hutchings, G. J. Palladium-tin Catalysts for the Direct Synthesis of $\mathrm{H}_{2} \mathrm{O}_{2}$ with High Selectivity. Science 2016, 351 (6276), 965-968.

(14) Savara, A.; Chan-Thaw, C. E.; Sutton, J. E.; Wang, D.; Prati, L.; Villa, A. Molecular Origin of Selectivity Differences Between Pd and AuPd in Benzyl Alcohol Oxidation: Different Oxygen Adsorption Properties. ChemCatChem 2017, 2, 253-260.

(15). Hilaire, L. L. g., P.; Holl, Y.; Maire, G. Interaction of Oxygen and Hydrogen with Pd-Au Alloys: An AES and XPS Study. Surf. Sci. 1981, 103, 125-140.

(16). Adria R. Wilson, K. S., Miaofang Chi, Ryan M. White, James M. LeBeau, H. Henry Lamb and Benjamin J. Wiley. From Core-Shell to Alloys: The Preparation and Characterization of Solution-Synthesized AuPd Nanoparticle Catalysts. J. Phys. Chem. C 2013, 117, 17557-17566.

(17). Fu, Q.; Yang, Fan.; Bao, Xinhe.; Interface-Confined Oxide Nanostructures for Catalytic Oxidation Reactions. Accounts Chem. Res. 2013, 46, , 1169-1701.

(18). Huda, M.; Minamisawa, K.; Tsukamoto, T.; Tanabe, M.; Yamamoto, K. Aerobic Toluene Oxidation Catalyzed by Subnano Metal Particles. Angew. Chem. Int. 
Edit. 2019, 58 (4), 1002-1006.

(19). Vinod Kumar Puthiyapura, D. J. L. B., Andrea E. Russe, Wen-Feng Lin and Christopher Hardacre. Biobutanol as Fuel for Direct Alcohol Fuel Cells Investigation of Sn-Modified Pt Catalyst for Butanol Electro-oxidation. ACS Appl. Mater. Inter. 2016, $8,12859-12870$.

(20). Bai, X.; Chen, W.; Zhao, C.; Li, S.; Song,Y.; Ge, R.; Wei, W.; Sun, Y. Exclusive Formation of Formic Acid from $\mathrm{CO}_{2}$ Electroreduction by Tunable Pd-Sn Alloy. Angew. Chem. Int. Edit. 2017, 56 (40), 12219-12223.

(21). Clarke, J. Selectivity in Catalysis by Alloys. Chem. Rev. 1975, 75 (3), 291-305.

(22). Vicente, A.; Lafaye, G.; Especel, C.; Marécot, P.; Williams, C. T. The Relationship Between the Structural Properties of Bimetallic $\mathrm{Pd}-\mathrm{Sn} / \mathrm{SiO}_{2}$ Catalysts and Their Performance for Selective Citral Hydrogenation. J. Catal. 2011, 283 (2), 133-142.

(23). Xu, J.; Wang, Y.; Cao, Y.; He, Z.; Zhao, L.; Etim, U. J.; Bai, P.; Yan, Z.; Wu, P. What is the Effect of Sn and Mo Oxides on Gold Catalysts for Selective Oxidation of Benzyl Alcohol? New J. Chem. 2019, 43 (6), 2591-2599.

(24). Delley, B. An All-electron Numerical Method for Solving the Local Density Functional for Polyatomic Molecules. J. Chem. Phys. 1990, 92 (1), 508-517.

(25). Delley, B. Fast Calculation of Electrostatics in Crystals and Large Molecules. J. Phys. Chem. 1996, 100 (15), 6107-6110.

(26). Perdew, J. P.; Burke, K.; Ernzerhof, M. Generalized Gradient Approximation 
Made Simple. Phys. Rev. Lett. 1996, 77 (18), 3865-3868.

(27). Grimme, S. Semiempirical GGA-type Density Functional Constructed with a Long-range Dispersion Correction. J. Comput. Chem. 2006, 27 (15), 1787-1799.

(28). Zhao, L. G., S.; Liu, H.; Zhu, H.; Yuan, S.; Guo, W. Density Functional Study of Hydrogen Evolution on Cobalt-Embedded Carbon Nanotubes: Effects of Doping and Surface Curvature. ACS Appl. Nano Mater. 2018, 1, 6258-6268.

(29). Halgren, T. A.; Lipscomb, W. N. The Synchronous-transit Method for Determining Reaction Pathways and Locating Molecular Transition States. Chem. Phys. Lett. 1977, 49 (2), 225-232.

(30). Alwan, A. M.; Hashim, D. A.; Jawad, M. F. Efficient Modified Bimetallic Alloy Nanoparticles Porous Silicon Gas Sensors for CO Gas Detection Process. Solid-State Electron. 2019, 153, 37-45.

(31). Dong, Q.; Wu, M.; Mei, D.; Shao, Y.; Wang, Y.; Liu, J.; Li, H.; Hong, L. Multifunctional Pd-Sn Electrocatalysts Enabled by In-situ Formed $\mathrm{SnO}_{\mathrm{x}}$ and $\mathrm{TiC}$ Triple Junctions. Nano Energy 2018, 53, 940-948.

(32). Tsud, N.; Johanek, V.; Stara, I.; Veltruská, K.; Matolın, V. XPS, ISS and TPD Study of Pd-Sn Interactions on $\mathrm{Pd}-\mathrm{SnO}_{\mathrm{x}}$ Systems. Thin Solid Films 2001, 391 (2), 204-208.

(33). Pushkarev, A. S.; Pushkareva, I. V.; Ivanova, N. A.; du Preez, S. P.; Bessarabov, D.; Chumakov, R. G.; Stankevich, V. G.; Fateev, V. N.; Evdokimov, A. A.; Grigoriev, S. A. Pt/C and Pt/SnO ${ }_{\mathrm{x}} / \mathrm{C}$ Catalysts for Ethanol Electrooxidation: Rotating Disk Electrode Study. Catalysts 2019, 9 (3), 271. 
(34). Wu, P.; Huang, Y.; Kang, L.; Wu, M.; Wang, Y. Multisource Synergistic Electrocatalytic Oxidation Effect of Strongly Coupled PdM $(\mathrm{M}=\mathrm{Sn}, \mathrm{Pb}) / \mathrm{N}$-doped Graphene Nanocomposite on Small Organic Molecules. Sci. Rep. 2015, 5 (1), 14173.

(35). Elnaggar, M. E.; Shaheen, T. I.; Fouda, M. M.; Hebeish, A. A. Eco-friendly Microwave-assisted Green and Rapid Synthesis of Well-stabilized Gold and Core-shell Silver-gold Nanoparticles. Carbohyd. Polym. 2016, 136, 1128-1136.

(36). Tiruvalam, R.; Pritchard, J.; Dimitratos, N.; Lopez-Sanchez, J.; Edwards, J.; Carley, A.; Hutchings, G.; Kiely, C. Aberration Corrected Analytical Electron Microscopy Studies of Sol-immobilized Au+Pd, Au $\{\mathrm{Pd}\}$ and $\mathrm{Pd}\{\mathrm{Au}\}$ Catalysts Used for Benzyl Alcohol Oxidation and Hydrogen Peroxide Production. Faraday Discuss. 2011, 152, 63-86.

(37). Silva, T. A. G.; Teixeira-Neto, E.; Lopez, N.; Rossi, L. M., Volcano-like Behavior of Au-Pd Core-shell Nanoparticles in the Selective Oxidation of Alcohols. Sci. Rep. 2014, 4, 5766-5771.

(38). Kruse, N. XPS Characterization of $\mathrm{Au} / \mathrm{TiO}_{2}$ Catalysts: Binding Energy Assessment and Irradiation Effects. Appl. Catal. A-Gen. 2011, 391 (1), 367-376.

(39). Wang, T.; Yuan, X.; Li, S.; Zeng, L.; Gong, J. CeO-modified Au@ SBA-15 Nanocatalysts for Liquid-phase Selective Oxidation of Benzyl Alcohol. Nanoscale 2015, 7 (17), 7593-7602.

(40). Arrii, S.; Morfin, F.; Renouprez, A. J.; Rousset, J. L. Oxidation of CO on Gold Supported Catalysts Prepared by Laser Vaporization: Direct Evidence of Support Contribution. J. Am. Chem. Soc. 2004, 126 (4), 1199. 
(41). Liu, N.; Xu, M.; Yang, Y.; Zhang, S.; Zhang, J.; Wang, W.; Zheng, L.; Hong, S.; Wei, M. $\mathrm{Au}^{\delta-}-\mathrm{O}_{\mathrm{v}}-\mathrm{Ti}^{3+}$ Interfacial Site: Catalytic Active Center toward Low-Temperature Water Gas Shift Reaction. ACS Catal. 2019, 9 (4), 2707-2717.

(42). Mohammad, M.; Nishimura, S.; Ebitani, K. In Selective Aerobic Oxidation of 1, 3-propanediol to 3-hydroxypropanoic Acid Using Hydrotalcite Supported Bimetallic Gold Nanoparticle Catalyst in Water. AIP Conference Proceedings. American Institute of Physics 2015, 1649(1), 58-66.

(43). Brun, M.; Berthet, A.; Bertolini, J. C. XPS, AES and Auger Parameter of Pd and PdO. J. Electron Spectrosc. 1999, 104 (1-3), 55-60.

(44). Cao, X.; Cao, L.; Yao, W.; Ye, X. Structural Characterization of Pd-doped $\mathrm{SnO}_{2}$ Thin Films Using XPS. Surf. Interface Anal. 1996, 24 (9), 662-666.

(45). Gabasch, H.; Unterberger, W.; Hayek, K.; Klötzer, B.; Kleimenov, E.; Teschner, D.; Zafeiratos, S.; Hävecker, M.; Knop-Gericke, A.; Schlögl, R. In situ XPS Study of Pd(1 11 1) Oxidation at Elevated Pressure, Part 2: Palladium Oxidation in the $10^{-1}$ mbar Range. Surf. Sci. 2006, 600 (15), 2980-2989.

(46). Wang, P.; Yuan, T.; Yuan, H.; Zheng, X.; Ijaz, H.; Hui, J.; Fan, D.; Zhao, Y.; $\mathrm{Hu}, \mathrm{S} . \mathrm{PdO} / \mathrm{SnO}_{2}$ Heterostructure for Low-temperature Detection of $\mathrm{CO}$ with Fast Response and Recovery. RSC Adv. 2019, 9 (40), 22875-22882.

(47). Priolkar, K. R.; Bera, P.; Sarode, P. R.; Hegde, M. S.; Emura, S.; Kumashiro, R.; Lalla, N. P. Formation of $\mathrm{Ce}_{1-\mathrm{x}} \mathrm{Pd}_{\mathrm{x}} \mathrm{O}_{2-\delta}$ Solid Solution in Combustion-Synthesized $\mathrm{Pd} / \mathrm{CeO}_{2}$ Catalyst: XRD, XPS, and EXAFS Investigation. Chem. Mater. 2002, 14 (5), 2120-2128. 
(48). Liu, C.; Kuang, Q.; Xie, Z.; Zheng, L. The Effect of Noble Metal (Au, Pd and $\mathrm{Pt}$ ) Nanoparticles on the Gas Sensing Performance of $\mathrm{SnO}_{2}$-based Sensors: A Case Study on the $\{221\}$ High-index Faceted $\mathrm{SnO}_{2}$ Octahedra. CrystEng Comm 2015, $17(33), 6308-6313$.

(49). Chen, Y.; Wang, H.; Liu, C. J.; Zeng, Z.; Zhang, H.; Zhou, C.; Jia, X.; Yang, Y. Formation of Monometallic $\mathrm{Au}$ and $\mathrm{Pd}$ and Bimetallic $\mathrm{Au}-\mathrm{Pd}$ Nanoparticles Confined in Mesopores via Ar Glow-discharge Plasma Reduction and Their Catalytic Applications in Aerobic Oxidation of Benzyl Alcohol. J. Catal. 2012, 289, 105-117.

(50). Li, L.; Zhang, N.; He, H.; Zhang, G.; Song, L.; Qiu, W. Shape-controlled Synthesis of Pd Nanocrystals with Exposed $\{110\}$ Facets and Their Catalytic Applications. Catal. Today 2019, 327, 28-36.

(51). Agostini, G.; Lamberti, C.; Pellegrini, R.; Leofanti, G.; Giannici, F.; Longo, A.; Groppo, E. Effect of Pre-reduction on the Properties and the Catalytic Activity of Pd/carbon Catalysts: A Comparison with $\mathrm{Pd} / \mathrm{Al}_{2} \mathrm{O}_{3}$. ACS Catal. 2014, 4 (1), 187-194.

(52). Wu, Y.; Tan, L.; Zhang, T.; Xie, H.; Yang, G.; Tsubaki, N.; Chen, J. Effect of Preparation Method on $\mathrm{ZrO}_{2}$-based Catalysts Performance for Isobutanol Synthesis from Syngas. Catalysts 2019, 9 (9), 752.

(53). Takashi Fujita, T. I., Kohei Shibamoto, Tetsuo Honma, Hironori Ohashi, Toru Murayama, and Masatake Haruta. CO Oxidation over Au/ZnO: Unprecedented Change of the Reaction Mechanism at Low Temperature Caused by a Different $\mathrm{O}_{2}$ Activation Process. ACS Catal. 2019, 9 ( 9), 8364-8372.

(54). Wang, H.; Liu, C.-j. Preparation and Characterization of SBA-15 Supported 
Pd Catalyst for CO Oxidation. Appl. Catal. B-Environ. 2011, 106 (3-4), 672-680.

(55). Dai, Q.; Zhu, Q.; Lou, Y.; Wang, X. Role of Brønsted Acid Site During Catalytic Combustion of Methane Over PdO/ZSM-5: Dominant or Negligible? J. Catal. 2018, 357, 29-40.

(56). Yu, W.; Mullen, G. M.; Mullins, C. B. Hydrogen Adsorption and Absorption with Pd-Au Bimetallic Surfaces. J. Phys. Chem. C 2013, 117 (38), 19535-19543.

(57). Yang, G.; Frenkel, A. I.; Su, D.; Teng, X. Enhanced Electrokinetics of C-C Bond Splitting During Ethanol Oxidation by Using a $\mathrm{Pt} / \mathrm{Rh} / \mathrm{Sn}$ Catalyst with a Partially Oxidized Pt and $\mathrm{Rh}$ Core and a $\mathrm{SnO}_{2}$ Shell. ChemCatChem 2016, 8 (18), 2876-2880.

(58) Wu, P.; Liu, H.; Cao, Y.; Xi, S.; Li, Z.; He, Z.; Song, L.; Xu, J.; Bai, P.; Zhao, L.; Mintova, S.; Yan, Z. Mesostructured Cellular Foam Silica Supported Au-Pt Nanoalloy: Enrichment of D-state Electrons for Promoting the Catalytic Synergy. Micropor. Mesopor. Mat., 2021, 316, 110982.

(59) Savara, A.; Chan-Thaw, C. E.; Rossetti, I.; Villa, A.; Prati, L.; Benzyl Alcohol Oxidation on Carbon-Supported Pd Nanoparticles: Elucidating the Reaction Mechanism. ChemCatChem 2014, 6, 3464-3473.

(60) Savara, A.; Rossetti, I.; Chan-Thaw, C. E.; Prati, L.; Villa, A. Microkinetic Modeling of Benzyl Alcohol Oxidation on Carbon-Supported Palladium Nanoparticles ChemCatChem 2016, 8, 1-11. 
For Table of Content use only 


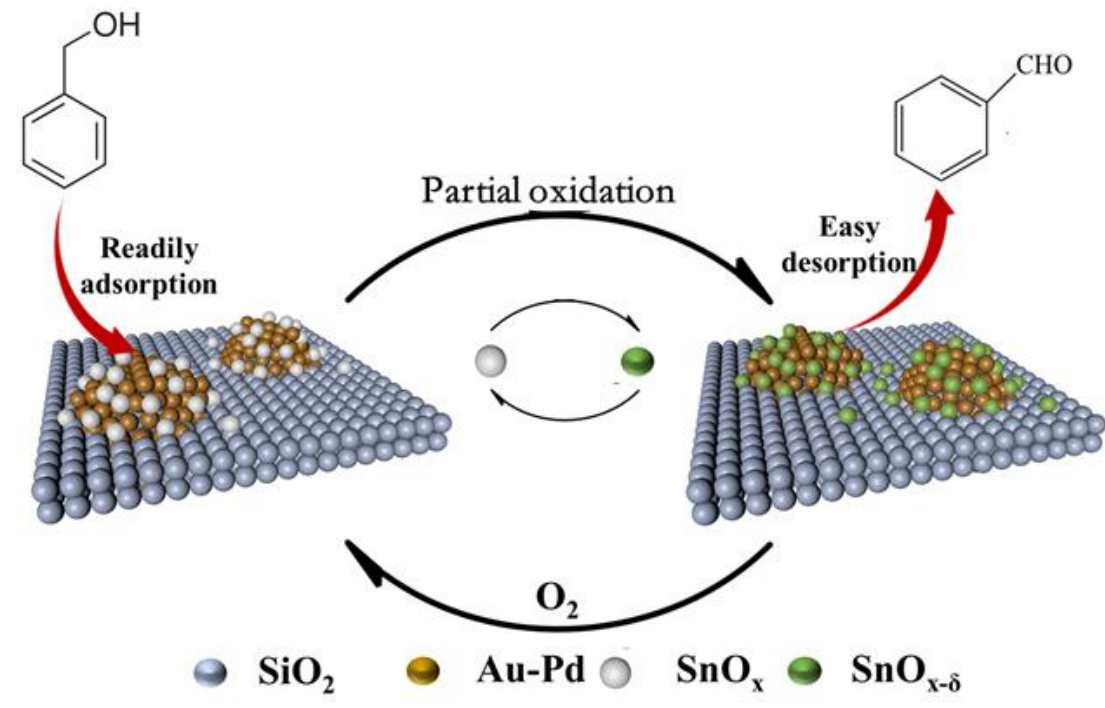

